\title{
General patterns of sexual dimorphism in graylings (Thymallus), with a comparison to other salmonid species
}

\author{
Gernot K. Englmaier $(\mathbb{D} \cdot$ Alexander Antonov $•$ Steven J. Weiss $\mathbb{D}$
}

Received: 15 March 2021 / Accepted: 27 November 2021 / Published online: 15 December 2021

(C) The Author(s) 2021

\begin{abstract}
Among fishes, salmonids (family Salmonidae) have attracted a great deal of research attention focused on sexual dimorphism and associated selective forces. Most of this research has been directed toward anadromous and mostly semelparous salmon and trout (Oncorhynchus, Salmo), and comparatively little is known about intersexual variability in strictly iteroparous freshwater salmonids. We examined a comprehensive data set of 28 linear morphometric characters in 11 of 15 currently recognised species of grayling (Thymallinae, Thymallus), a genus consisting of iteroparous species only, to identify general patterns of intersexual morphological variability. Overall, we found that all grayling species show common sex-specific traits particularly relating to size dimensions of the dorsal, anal, pelvic and pectoral fins. Although the magnitude of sexual dimorphism differed among species, there was no significant phylogenetic signal associated with these
\end{abstract}

Supplementary Information The online version contains supplementary material available at https://doi.org/10.1007/ s11160-021-09694-4.

G. K. Englmaier $(\varangle) \cdot$ S. J. Weiss

Institute of Biology, University of Graz, Universitätsplatz

2, 8010 Graz, Austria

e-mail: gernot.englmaier@uni-graz.at

\section{A. Antonov}

Far Eastern Division, Institute of Water and Ecological Problems, Russian Academy of Sciences, Khabarovsk, Russia differences across the genus. These results are discussed in terms of the assumed selection pressures driving sexual dimorphism in graylings and are compared to existing knowledge in Salmonidae as a whole where similarities and differences with both Salmoninae and Coregoninae exist. The present study provides the first detailed genus-wide comparison of sexually dimorphic phenotypic characters in graylings, and highlights the need for more large-scale comparative studies in multiple salmonid species to better understand general macroevolutionary trends among this important group of freshwater fishes.

Keywords Salmonidae - Sexual selection - Dorsal fin · Anal fin · Morphology $\cdot$ Secondary sexual characters

\section{Introduction}

In many animal taxa, a key aspect of intraspecific variability is associated with sexual dimorphism (Andersson 1994), the differences in physiology, morphology and behaviour of conspecific males and females (sensu Punzalan and Hosken 2010). By introducing the idea of sexual selection (Darwin 1871), Darwin set the stage for the general recognition of sex-specific roles in shaping organismal diversity. Although both empirical and theoretical studies 
suggest that the evolution and maintenance of sexspecific traits is more complex, also involving other selection mechanisms (e.g. Hedrick and Temeles 1989; Cooper 2010), the theory of sexual selection is still fundamental to a general understanding of intersexual variability (Clutton-Brock 2007).

The general mechanisms that drive the evolution of sexual dimorphism are well studied in several taxonomic groups including insects (Wilhelm et al. 2011), birds (Berns and Adams 2012), mammals (Swanson et al. 2013), reptiles (Agha et al. 2017), fishes (Oke et al. 2019) and amphibians (Pincheira-Donoso et al. 2021). Among fishes, salmonids (family Salmonidae) have become one of the most frequently studied groups of species used to address questions on the evolution of sexual dimorphism and associated selective forces (Fleming and Reynolds 2004). Salmonids are a diverse group of cold-water adapted fishes in the northern hemisphere and include salmon and trout (Oncorhynchus, Salmo), lenok (Brachymystax), taimen (Hucho), Sakhalin taimen (Parahucho), char (Salvelinus), whitefish and cisco (Coregonus), Round whitefish (Prosopium), inconnu (Stenodus), and grayling (Thymallus). Many salmonid species, particularly semelparous Pacific salmon (Oncorhynchus), undergo dramatic phenotypic change during the reproductive period, which includes the development of an elongated snout, enlarged teeth, hooked jaws, dorsal hump, elongated fins, thickened skin, and bright colouration (Fleming and Gross 1994; Quinn and Foote 1994). These exaggerated traits are usually male-biased (i.e. larger, thicker or more pronounced in males) and are assumed to have evolved as a consequence of sexual selection where males compete for fertilization opportunities (Fleming and Reynolds 2004). The presence and degree of sexual dimorphism in these traits differ between taxonomic groups and show great intraspecific variability, which often is habitat associated (Johnson et al. 2006; Oke et al. 2019).

Despite extensive research on sexually dimorphic characters in salmonids, the generality of these traits remains poorly investigated. So far, most attention has been given to large anadromous and semelparous species, with few studies addressing sexual dimorphism in iteroparous and/or freshwater salmonids. Graylings (subfamily Thymallinae) are freshwater resident iteroparous species with a suite of distinctive morphological traits potentially relevant for the study of sexual dimorphism (Fig. 1). In comparison to other salmonids, graylings are easily characterised by their greatly enlarged dorsal fin, which often has a speciesspecific coloration pattern, that is not, at least not overtly, sex-specific (Knizhin 2009) and is known to undergo secondary sexual development (Ward 1951). While taxonomy and species level phylogeny in graylings are becoming well-resolved in recent years (Knizhin 2009; Weiss et al. 2021), the evolution of sexual dimorphism remains poorly studied, having only been addressed at all in a few species (e.g. Mikheev 2009). Increasing knowledge on sympatric occurrence of multiple grayling species (Shubin and Zakharov 1984; Weiss et al. 2007, 2020, 2021), with little evidence of hybridization and introgression (Froufe et al. 2003; Weiss et al. 2007, 2020; Persat et al. 2016), has drawn increasing attention to elucidating the mechanisms that might support reproductive isolation.

Graylings are a monophyletic sister clade to Coregoninae (Campbell et al. 2020) and are widespread across most of Europe, Siberia, the Russian Far East and some parts of North America (Weiss et al. 2021). They are typical riverine fish, but also occur in many lacustrine habitats across their range, and spawn in spring or early summer after short or medium distanced potamodromous migrations (usually from lakes to rivers and within rivers). Graylings are gravel spawning salmonids, where both males and females are promiscuous with multiple spawning acts, usually involving different mates (Beauchamp 1990). In contrast to most other river spawning salmonids, dominant males occupy and defend spawning territories prior to the arrival of females (Fabricius and Gustafson 1955; Bishop 1971). Observations of frequent territorial contests and the generally increased aggressive behaviour during spawning season (Fabricius and Gustafson 1955) may suggest strong intrasexual (male-male) competition for territories and access to mates. Likewise, territorial contests as well as courtship and spawning include characteristic behaviours such as the specific display of the colourful dorsal and pelvic fins (Fabricius and Gustafson 1955; Kratt and Smith 1980). Intraspecific competition, however, is not restricted to the spawning season. Similar to other drift-feeding stream salmonids (Fausch and White 1981), feeding positions among graylings are established in dominance hierarchies (Hughes and Dill 1990; Hughes 1992) where the characteristic display of the dorsal and pelvic fins is an 

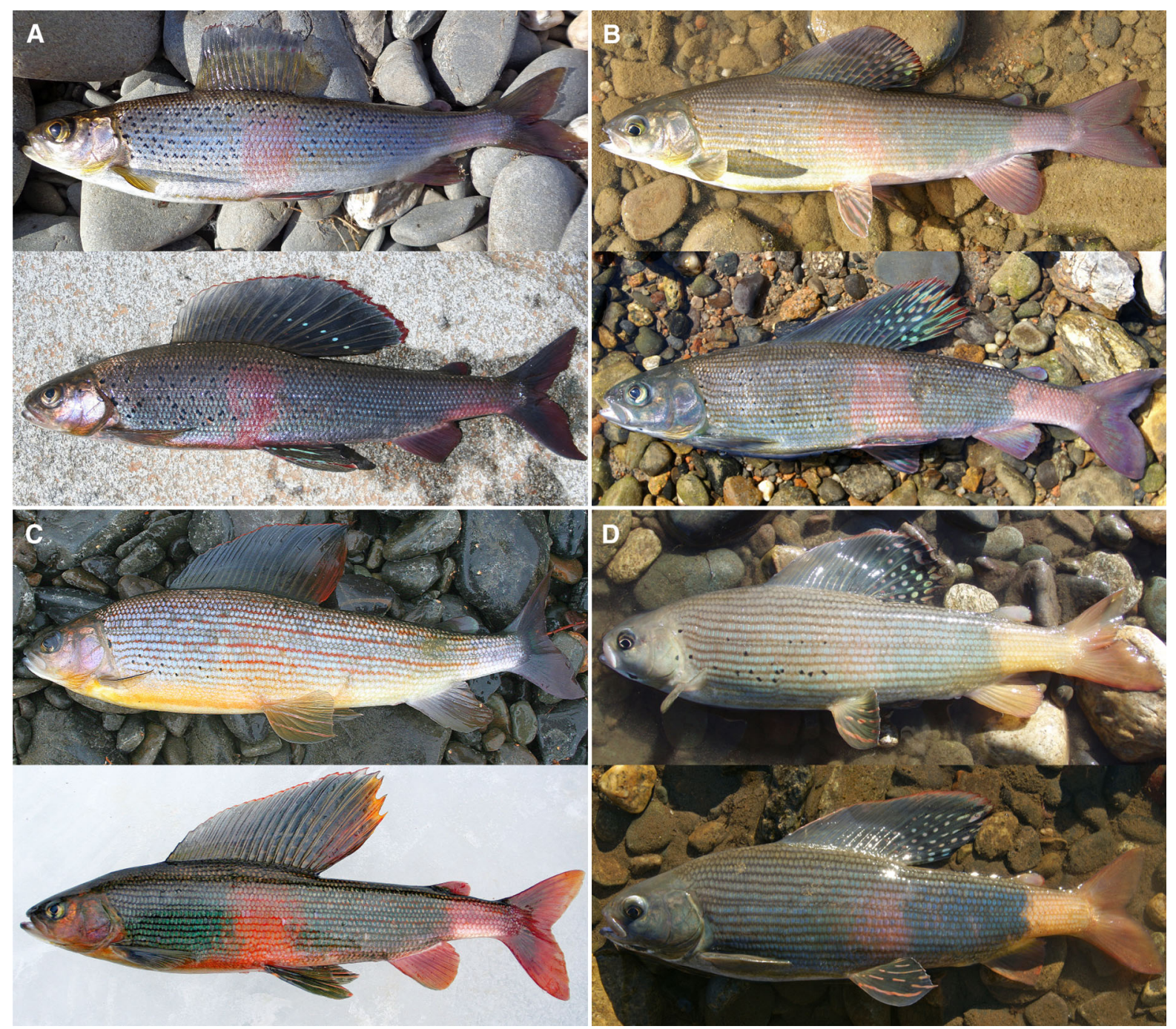

Fig. 1 Phenotypic comparison of female (above) and male (below) graylings in A T. grubii, during spawning season, both female and male from the Bureya River, Russia; B $T$. baicalensis, outside spawning season, both female and male from the Delger mörön River, Mongolia; C T. flavomaculatus,

integral behavioural element (Fabricius and Gustafson 1955; Tack 1973).

Given this general behavioural framework and the assumption that selective forces shaping sexually dimorphic phenotypic characters are closely linked to the reproductive behaviour in salmonids (Fleming and Reynolds 2004), we hypothesize that the extent and direction of sexual dimorphism in graylings might be consistent across different species. Thus, we analysed a comprehensive data set of linear morphometric traits to identify general trends of sexual

during spawning season, female from the Pody River and male from the Gobilly River, Russia; D T. svetovidovi, outside spawning season, both female and male from the Sharga Gol, Mongolia. Photos by A. Antonov (A, C) and C. Ratschan (B, D)

dimorphism in graylings. Furthermore, we reviewed external morphometric characters subject to sexual dimorphism among salmonids (Salmoninae, Coregoninae, Thymallinae) in order to place our results in a broader phylogenetic context. Finally, by summarizing areas of potential future studies, we hope to foster cross-disciplinary research in ecology and evolution of graylings, which may aid future conservation and management efforts targeting this group of freshwater fishes. 


\section{Materials and methods}

Morphological data set

To test for general patterns of sexual dimorphism among graylings, we analysed a large morphological data set established over a period of more than 10 years and spanning $>1500$ individual specimens from 11 species across the whole distribution range of the genus (Table 1). Many subsets of the data set have been used in a range of taxonomic, systematic, and evolutionary studies to date (e.g. Froufe et al. 2003; Knizhin et al. 2004, 2006a, b, c, d, 2007, 2008a, b; Knizhin and Weiss 2009; Knizhin 2009; Weiss et al. 2006, 2020), but the data have never been investigated as a whole nor in the context of sexual dimorphism. Twenty-eight linear measurements following those introduced by Svetovidov (1936), Pravdin (1966), and Knizhin et al. (2004) were made point to point or as a projection to midline using a caliper to the nearest $0.1 \mathrm{~mm}$ (Fig. 2, Table S1). Measurements were taken from formalin (4\%) preserved specimens.

Sex and stage of maturity were determined by visual examination of gonads following the classification of ovarian reproductive stages by Sakun and Butskaya (1968). Fishes of stage I (oogonia and oocytes did not yet start protoplasmic growth, immature condition) were excluded and only fishes between stage II (previtellogenic condition) and stage VI (postspawning condition, before returning to stage II) were included in the analysis. Most fishes were sampled after spawning season (July-October). Only few specimens of $T$. arcticus $(\mathrm{n}=23), T$. baicalensis $(\mathrm{n}=60)$ and $T$. thymallus $(\mathrm{n}=65)$ were taken before or during spawning season in spring or early summer.

\section{Data transformation}

In order to emphasize general trends in the data set as well as equalize variances among groups, we excluded measurements showing extreme values. These were defined as the deviation of $3 * \mathrm{IQR}$ (inter quartile range) from the 25 th $\left(\mathrm{Q}_{1}-3 * \mathrm{IQR}\right)$ and 75 th $\left(\mathrm{Q}_{3}+3\right.$ * IQR) percentile respectively, calculated using raw measurements relative to body length (referring to fork length). We excluded extreme values for each species and sex separately, rather than the entire data set, to retain the natural species-specific variability. In total, 52 specimens (3.3\% of the entire data set) were excluded (19 males, 33 females). The final data set consisted of measurements for 1539 fish (806 males and 733 females) (Table 1). For a few individuals, some measurements were not obtained due to damage or poor preservation condition. To retain these specimens in the analyses, predicted values from linear regression models (per sex, species and trait) were used to substitute missing data. Such cases account for $0.6 \%$ of the entire data $(0.7 \%$ of males and $0.6 \%$ of females).

All morphometric measurements were converted to their base 10 logarithm to linearize allometry and equalize variances (Sidlauskas et al. 2011). We evaluated potential allometric scaling among species by comparing species-specific slopes of reduced-
Table 1 Number of male and female specimens used in the analysis and mean fork length ( $\mathrm{Lsm} \pm \mathrm{SD})$ for each species

\begin{tabular}{|c|c|c|c|c|}
\hline \multirow[t]{2}{*}{ Species } & \multicolumn{2}{|c|}{ Male } & \multicolumn{2}{|c|}{ Female } \\
\hline & $\mathrm{N}$ & $\operatorname{Lsm}(\mathrm{mm})$ & $\mathrm{N}$ & $\operatorname{Lsm}(\mathrm{mm})$ \\
\hline T. arcticus & 102 & $280.4 \pm 63.7$ & 55 & $244.2 \pm 48.7$ \\
\hline T. baicalensis & 266 & $282.2 \pm 74.2$ & 265 & $297.2 \pm 60.5$ \\
\hline T. baicalolenensis & 158 & $213.6 \pm 38.6$ & 172 & $194.5 \pm 35.6$ \\
\hline T. brevirostris & 24 & $324.1 \pm 125.2$ & 22 & $345.9 \pm 120.5$ \\
\hline T. burejensis & 32 & $300.5 \pm 66.5$ & 35 & $288.7 \pm 59.1$ \\
\hline T. flavomaculatus & 25 & $233.2 \pm 29.8$ & 23 & $221.3 \pm 33.5$ \\
\hline T. grubii & 75 & $199.0 \pm 40.8$ & 50 & $173.4 \pm 27.0$ \\
\hline T. nigrescens & 15 & $280.9 \pm 25.0$ & 15 & $268.7 \pm 20.5$ \\
\hline T. svetovidovi & 11 & $370.7 \pm 13.9$ & 12 & $368.1 \pm 12.9$ \\
\hline T. thymallus & 66 & $330.5 \pm 44.6$ & 58 & $300.3 \pm 37.4$ \\
\hline T. tugarinae & 32 & $215.9 \pm 21.0$ & 26 & $204.6 \pm 24.9$ \\
\hline
\end{tabular}



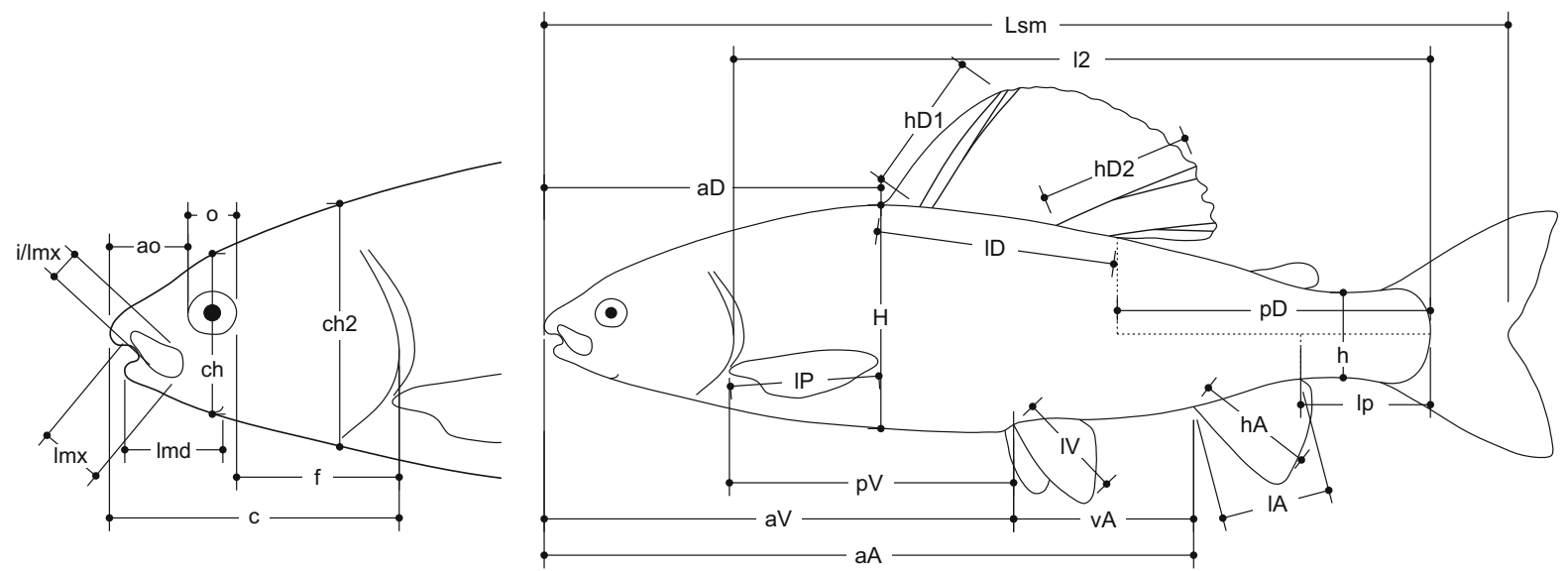

Fig. 2 Schematic illustration of morphometric characters used in the present study. For a detailed description of each measurement see Table S1. Lsm, fork length; 12, trunk length; ao, snout length; o, horizontal eye diameter; f, postorbital length; c, head length; ch2, head depth at nape; ch, head depth through the eye; lmx, upper jaw length; i/lmx, upper jaw depth; lmd, lower jaw length; $\mathrm{H}$, maximum body depth; $\mathrm{h}$, minimal caudal peduncle depth; $\mathrm{aD}$, predorsal length; $\mathrm{pD}$, postdorsal

major axis regression lines as outlined in Sidlauskas et al. (2011) and implemented in the R package 'smatr' (Warton et al. 2006) in R v.4.1.0 (R Core Team 2021). Some statistically significant differences among species were found (14 of 55 pairwise comparisons; Table S2). These differences, however, appeared related to sample size and body-size differences (Table 1), and thus we chose to apply a common slope in the following data transformation. To control for the effects of variation in body size and body size scaling, all morphometric traits were scaled to a common mean fork length using an allometric growth formula commonly applied in Salmonidae (Siwertsson et al. 2013; Jacobs et al. 2020): $\log _{10} \mathrm{Y}_{\mathrm{std}}=\log _{10}$ $\mathrm{Y}_{\mathrm{obs}}+\mathrm{b} *\left(\log _{10} \mathrm{~L}_{\mathrm{std}}-\log _{10} \mathrm{~L}_{\mathrm{obs}}\right)$; where $\mathrm{Y}_{\text {std }}$ is the corrected trait value, $\mathrm{Y}_{\mathrm{obs}}$ is the measured trait value, $\mathrm{b}$ is the slope of the regression of each $(\log 10)$ trait against $(\log 10)$ fork length, $\mathrm{L}_{\mathrm{std}}$ is the mean fork length of all specimens $(\mathrm{mm})$, and $\mathrm{L}_{\mathrm{obs}}$ is the individual fork length. Terminology of these variables follows Siwertsson et al. (2013). The common slope $b$ for each trait was derived from ANCOVA models using species and sex as factors while controlling for body length. length; aA, preanal length; $\mathrm{aV}$, prepelvic length; lp, caudal peduncle length; $\mathrm{pV}$, pectoral-pelvic distance; vA, pelvic-anal distance; $1 \mathrm{D}$, length of dorsal fin base; $\mathrm{hD} 1$, height of anterior part of dorsal fin; hD2, height of posterior part of dorsal fin; 1A, length of anal fin base; hA, height of anal fin; $1 \mathrm{~V}$, length of pelvic fin; 1P, length of pectoral fin. Not illustrated are: $k$, forehead width; w, maximum width of body

Comparison of sexual dimorphism among graylings

We determined morphological characters contributing to the divergence between males and females, across the whole genus, using a two-way Analysis of Variance (ANOVA). ANOVA models (trait $\sim \operatorname{sex}+$ species + species $*$ sex) were implemented in IBM SPSS Statistics v.26. A series of one-way ANOVA analyses with simple effects was additionally used to more precisely evaluate species-specific trends of sexual dimorphism. The assumptions of homoscedasticity and normal distribution of (unstandardized) residuals were not met in all cases. However, visual examination of residuals in histograms and normal QQ plots showed them to be approximately normally distributed. Overall, ANOVA analyses on large samples sizes ( $>500$ observations) are known to be robust against minor deviations of normality (e.g. Johnson 1998). To corroborate two-way ANOVA results and account for different sample sizes in sub-groups (i.e. species), we examined Welch's tests (unequal variance t-test) in cases where homogeneity of variances was not met (Ruxton 2006), and performed separate non-parametric Kruskal-Wallis tests to support oneway ANOVA results of species-specific trends where normality of residuals was violated. 
Phylogenetic comparative analysis

Because species are not independent and patterns of sexual dimorphism could have a phylogenetic component, we estimated the ancestral state of sexual dimorphism for each character and tested for a phylogenetic signal across species. The phylogenetic reconstruction is based on complete mitochondrial genomes of 15 Thymallus species (considering the current taxonomy presented in Weiss et al. (2021)) and two Coregonus species as outgroup with the following GenBank accession numbers: MT063012 (T. arcticus), MT063023 (T. baicalensis), MT063019 ( $T$. baicalolenensis), MT063036 (T. brevicephalus), MT063033 (T. brevirostris), MT063037 (T. burejensis), MT063039 (T. flavomaculatus), MT063038 ( $T$. grubii), MT063028 (T. nigrescens), MT063030 ( $T$. nikolskyi), MT063004 (T. thymallus), KJ866485 ( $T$. tugarinae), CM031715 (C. clupeaformis), and NC_025576 (C. peled). Alignment and analyses of mitochondrial data follow Weiss et al. (2021). All parts of the analysis were performed in PhyloSuite v.1.2.2 (Zhang et al. 2020) and IQ-TREE (Nguyen et al. 2015) was used for maximum likelihood (ML) analysis. The computed ML tree was visualised and edited with FigTree v.1.4.4 (Rambaut 2018) and CorelDRAW 2019.

For phylogenetic comparison, we excluded those species where morphological data were absent in our data set (T. aeliani, T. brevicephalus, T. ligericus, $T$. nikolskyi). We estimated and visualised the degree of sexual dimorphism in morphometric traits (based on mean pairwise differences (least square means) from linear two-way ANOVA models) at each node in the mtDNA phylogeny using the 'fastAnc' and 'contMap' functions in the R package 'phytools' (Revell 2012) in R v.4.1.0 ( $\mathrm{R}$ Core Team 2021). To test for a phylogenetic signal of sexual dimorphism for each character, we estimated Pagel's $\lambda$ (Pagel 1999) and Blomberg's K (Blomberg et al. 2003) using the 'phylosig' function in 'phytools'.

Literature review on sexually dimorphic traits in Salmonidae

To evaluate our observations in graylings in a broader phylogenetic context, we synthesized current knowledge of sexual dimorphism in external morphometric traits across Salmonidae. We included characters that are reversable and temporally linked to the breeding season as well as those that undergo a non-reversable change starting usually at the onset of sexual maturity. Sexual size dimorphism was not considered due to its high intraspecific variability (e.g. Jonsson and Jonsson 2015). Literature searches were performed in Web of Science, Scopus and Google Scholar (key words in different combinations: sexual dimorphism, secondary sexual character(s), morphometric character(s), female, male, salmonids, *subfamily*, *genus*, *trait*). The results were augmented with additional studies, especially from Russia, that were not found with these search engines. A morphometric trait was considered sexually dimorphic if a statistical analysis was performed to test for intersexual variability or the morphological characters were described as explicit sexual dimorphism.

\section{Results}

Comparison of sexual dimorphism among graylings

The average fork length among all individuals was $260.5 \pm 73.6 \mathrm{~mm}$. Males were larger than females in the global data set $(263.7 \pm 73.7 \mathrm{~mm}$ vs. $256.9 \pm$ $73.2 \mathrm{~mm}$; two-way ANOVA, $\mathrm{F}_{1,1517}=8.208$, $P=0.004 ;$ Welch, $\mathrm{F}_{1}, 1513.03=3.938, P=0.047$ ), but this pattern was not consistent across all species reflected by the significant species $\mathrm{x}$ sex interaction (Table 2). At the species-specific level, only $T$. arcticus, T. baicalolenensis, T. grubii and T. thymallus exhibited a significant male-biased size dimorphism (one-way ANOVA, F $<22.590, P<0.001$; Kruskal Wallis $\left.\mathrm{H}, \mathrm{X}^{2}<20.770, P<0.001\right)$.

Two-way ANOVA analyses on morphometric characters showed that significant species $\mathrm{x}$ sex interactions were present in 21 out of 28 traits. Significant differences between the sexes were found in 18 characters, 12 of which remained significant after table-wide Bonferroni correction (Table 2). When species-specific pairwise differences were examined, predorsal length, length of dorsal-fin base, height of anterior part of dorsal fin, height of posterior part of dorsal fin, height of anal fin, and length of the pelvic and pectoral fins showed a uniform pattern of sexual dimorphism (Figs. 3, S1), although these differences were not statistically significant for all 
Table 2 Two-way ANOVA results of fork length and 28 standardized morphometric characters. Least square means (LSM) for each trait and sex are given with their standard errors

\begin{tabular}{|c|c|c|c|c|c|c|c|c|c|c|c|}
\hline \multirow[t]{2}{*}{ Variables } & \multicolumn{5}{|l|}{ Sex } & \multicolumn{3}{|c|}{ Species } & \multicolumn{3}{|c|}{ Species x Sex } \\
\hline & LSM male & emale & $\mathrm{df}$ & $\mathrm{F}$ & $\begin{array}{l}P- \\
\text { value }\end{array}$ & df & $\mathrm{F}$ & $\begin{array}{l}P- \\
\text { value }\end{array}$ & df & $\mathrm{F}$ & $\begin{array}{l}P- \\
\text { value }\end{array}$ \\
\hline \multicolumn{12}{|l|}{ Body length } \\
\hline Fork length (Lsm) & $2.424 \pm 0.005$ & $2.404 \pm 0.005$ & 1 & 8.208 & 0.004 & 10 & 115.861 & 0.000 & 10 & 5.661 & 0.000 \\
\hline \multicolumn{12}{|l|}{ Morphometric charaters } \\
\hline runk length (12) & $2.306 \pm 0.000$ & $2.306 \pm 0.001$ & 1 & 0.004 & 0.953 & 10 & 26.847 & 0.000 & 10 & 2.897 & 0.001 \\
\hline Snout length (ao) & $1.198 \pm 0.002$ & $1.193 \pm 0.002$ & 1 & 3.071 & 0.080 & 10 & 92.154 & 0.000 & 10 & 4.078 & 0.000 \\
\hline Horizontal eye diameter (o) & $1.066 \pm 0.002$ & $1.068 \pm 0.002$ & 1 & 1.126 & 0.289 & 10 & 40.328 & 0.000 & 10 & 3.100 & 0.001 \\
\hline Ostorbital length (f) & $1.405 \pm 0.001$ & $1.404 \pm 0.001$ & 1 & 1.091 & 0.296 & 10 & 62.643 & 0.000 & 10 & 4.430 & 0.000 \\
\hline Head length (c) & $1.701 \pm 0.001$ & $1.698 \pm 0.001$ & 1 & 5.135 & 0.024 & 10 & 76.975 & 0.000 & 10 & 4.682 & 0.000 \\
\hline Head depth at nape $(\operatorname{ch} 2)$ & $1.583 \pm 0.001$ & $1.580 \pm 0.001$ & 1 & 2.528 & 0.112 & 10 & 92.117 & 0.000 & 10 & 3.184 & 0.001 \\
\hline $\begin{array}{l}\text { Head depth through the eye } \\
\text { (ch) }\end{array}$ & $1.425 \pm 0.002$ & $1.419 \pm 0.002$ & 1 & 6.571 & 0.011 & 10 & 65.819 & 0.000 & 10 & 3.365 & 0.000 \\
\hline Forehead width (k) & $1.181 \pm 0.002$ & $1.174 \pm 0.002$ & 1 & 5.104 & 24 & 10 & 26.916 & 0.000 & 10 & 2.174 & 0.017 \\
\hline Jpper jaw length $(\operatorname{lmx})$ & $1.164 \pm 0.002$ & $1.167 \pm 0.002$ & 1 & 1.168 & 0.280 & 10 & 72.336 & 0.000 & 10 & 5.296 & 0.000 \\
\hline Upper jaw depth (i/lmx) & $0.698 \pm 0.003$ & $0.694 \pm 0.003$ & 1 & 1.545 & 0.214 & 10 & 29.787 & 0.000 & 10 & 2.888 & 0.001 \\
\hline Lower jaw length (lmd) & $1.398 \pm 0.002$ & $1.397 \pm 0.002$ & 1 & 0.611 & 0.435 & 10 & 93.422 & 0.000 & 10 & 3.898 & 0.000 \\
\hline Im body depth $(\mathrm{H})$ & $1.739 \pm 0.002$ & $1.740 \pm 0.002$ & 1 & 750 & 7 & 10 & 23 & 0.000 & 10 & 0.681 & 0.743 \\
\hline $\begin{array}{l}\text { I caudal peduncle } \\
(\mathrm{h})^{*}\end{array}$ & $1.269 \pm 0.001$ & $1.262 \pm 0.001$ & 1 & 12.646 & 0.000 & 10 & 201.091 & 0.000 & 10 & 0.892 & 0.540 \\
\hline Maximum width of body (w) & $479 \pm 0.003$ & $1.491 \pm 0.003$ & 1 & .439 & 2 & 0 & 21 & .000 & 10 & 2.771 & 0.002 \\
\hline Predorsal length $(\mathrm{aD})^{*}$ & $1.922 \pm 0.001$ & $1.930 \pm 0.001$ & 1 & 42.958 & 0.000 & 10 & 357.146 & 0.000 & 10 & 3.269 & 0.000 \\
\hline Postdorsal length (pD) & $2.037 \pm 0.001$ & $2.042 \pm 0.000$ & 1 & 9.758 & 0.002 & 10 & 66.577 & 0.000 & 10 & 2.416 & 0.008 \\
\hline Preanal length $(\mathrm{aA})^{*}$ & $2.262 \pm 0.000$ & $2.266 \pm 0.001$ & 1 & 36 & 0 & 10 & 22.651 & 0.000 & 10 & 2.949 & 0.001 \\
\hline Prepelvic length (aV) & $2.076 \pm 0.001$ & $2.079 \pm 0.001$ & 1 & 8.548 & 0.004 & 10 & 38.705 & 0.000 & 10 & 2.179 & 0.017 \\
\hline Caudal peduncle length (lp) & $1.634 \pm 0.001$ & $1.635 \pm 0.001$ & 1 & 0.113 & 0.737 & 10 & 53.547 & 0.000 & 10 & 0.518 & 0.878 \\
\hline Pectoral-pelvic distance $(\mathrm{pV})^{*}$ & $1.864 \pm 0.001$ & $1.872 \pm 0.001$ & 1 & 24.976 & 0.000 & 10 & 18.483 & 0.000 & 10 & 1.213 & 0.277 \\
\hline Pelvic-anal distance (vA)* & $1.819 \pm 0.001$ & $1.825 \pm 0.001$ & 1 & 10.487 & 0.001 & 10 & 18.789 & 0.000 & 10 & 1.445 & 0.155 \\
\hline $\begin{array}{l}\text { Length of dorsal fin base } \\
\text { (ID)* }\end{array}$ & $1.780 \pm 0.002$ & $1.759 \pm 0.002$ & 1 & 69.945 & 0.000 & 10 & 316.737 & 0.000 & 10 & 1.966 & 0.033 \\
\hline $\begin{array}{l}\text { Height of anterior part of } \\
\text { dorsal fin }(\mathrm{hD} 1)^{*}\end{array}$ & $1.486 \pm 0.002$ & $1.455 \pm 0.003$ & 1 & 85.915 & 0.000 & 10 & 56.664 & 0.000 & 10 & 1.770 & 0.061 \\
\hline $\begin{array}{l}\text { Height of posterior part of } \\
\text { dorsal fin }(\mathrm{hD} 2)^{*}\end{array}$ & $1.585 \pm 0.005$ & $1.473 \pm 0.005$ & 1 & 257.779 & 0.000 & 10 & 147.709 & 0.000 & 10 & 8.347 & 0.000 \\
\hline Length of anal fin base (1A)* & $1.391 \pm 0.002$ & $1.369 \pm 0.002$ & 1 & 57.600 & 0.000 & 10 & 53.979 & 0.000 & 10 & 2.858 & 0.002 \\
\hline Height of anal fin $(\mathrm{hA})^{*}$ & $1.470 \pm 0.002$ & $1.512 \pm 0.002$ & 1 & 209.443 & 0.000 & 10 & 36.577 & 0.000 & 10 & 5.838 & 0.000 \\
\hline Length of pelvic fin (IV)* & $1.633 \pm 0.002$ & $1.595 \pm 0.002$ & 1 & 150.800 & 0.000 & 10 & 93.433 & 0.000 & 10 & 2.478 & 0.006 \\
\hline Length of pectoral fin $(\mathrm{lP})^{*}$ & $1.622 \pm 0.002$ & $1.612 \pm 0.002$ & 1 & 23.019 & 0.000 & 10 & 59.127 & 0.000 & 10 & 1.298 & 0.226 \\
\hline
\end{tabular}

Traits that remained significant after table-wide Bonferroni correction (significance level at $\alpha=0.05 / 28=0.0018$ ) are marked with an $*$

species (Table S2). The magnitude of sexual dimorphism showed considerable variation in some characters, exemplified by a sevenfold difference in magnitude of the posterior part of dorsal fin between $T$. 


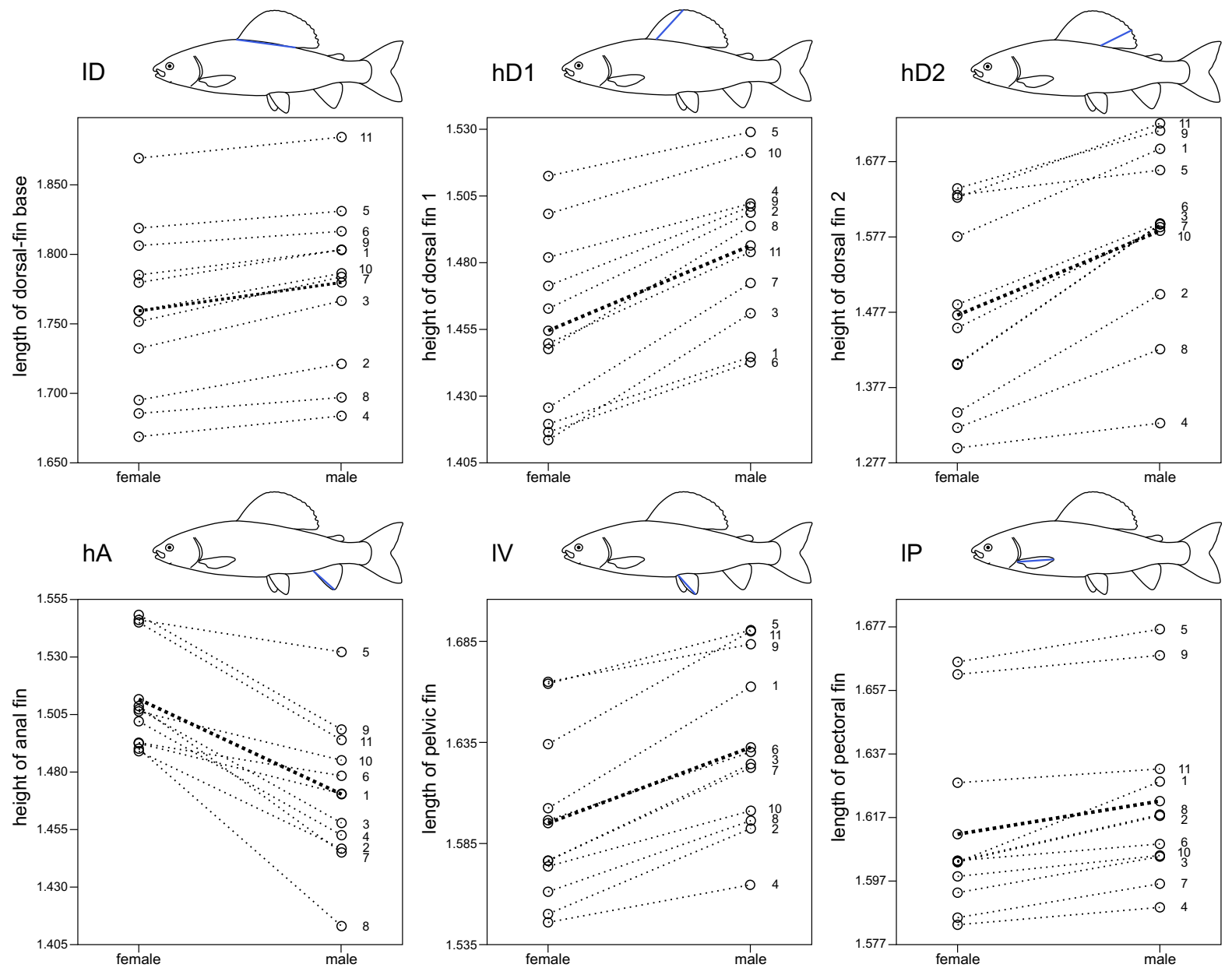

Fig. 3 Comparison of pairwise differences (least square means) for the most uniform sexually dimorphic traits of the dorsal, anal, pelvic and pectoral fins (two-way ANOVA, significant after table-wide Bonferroni correction). Bold lines represent mean values for all species. Height of dorsal fin 1 refers to height of anterior part of dorsal fin and height of dorsal fin 2 refers to

baicalolenensis $(0.187$, most dimorphic) and T. burejensis (0.033, least dimorphic).

In general, male graylings had significantly greater length and height dimensions of dorsal, pelvic and pectoral fins, a longer base of the anal fin, and a deeper caudal peduncle than conspecific females. In contrast, female-biased traits were related to the height of the anal fin, length dimensions of the abdomen, and a greater distance between the fins. Deviations from these general trends in T. brevirostris, $T$. burejensis, $T$. flavomaculatus, T. svetovidovi and T. tugarinae (Fig. S1), were not statistically significant (one-way height of posterior part of dorsal fin. $1=T$. arcticus, $2=T$. baicalensis, $3=T$. baicalolenensis, $4=T$. brevirostris, $5=T$. burejensis, $6=T$. flavomaculatus, $7=T$. grubii, $8=T$. nigrescens, $9=T$. svetovidovi, $10=T$. thymallus, $11=T$. tugarinae

ANOVA, F $<0.809, P>0.370$; Kruskal Wallis $\mathrm{H}$, $\left.\mathrm{X}^{2}<0.510, P>0.470\right)$.

While some attributes of the head and abdomen were non-significant in the global two-way ANOVA analyses, non-parametric Welch's tests suggested a significantly greater postorbital length (Welch, $\left.\mathrm{F}_{1,1518.36}=13.347, \quad P<0.001\right)$ and head length (Welch, $\mathrm{F}_{1},{ }_{1525.56}=10.651, P=0.001$ ) in males, and a greater body width (Welch, $\mathrm{F}_{1,1236.93}=11.917$, $P<0.001$ ), postdorsal length (Welch, $\left.\mathrm{F}_{1,1526.86}=48.073, P<0.001\right)$ and preventral length (Welch, $\mathrm{F}_{1}, 1536.71=27.415, P<0.001$ ) in females. These traits were found significant for sex- 
differentiation only in a few species (Table S2), although the direction of sexual dimorphism was similar for most species.

Phylogenetic comparative analysis

Overall, there was no significant phylogenetic signal of sexual dimorphism among the traits (Pagel's $\lambda<0.001 \quad(P=1), \quad$ Blomberg's $\quad \mathrm{K}<0.782$ $(P>0.160))$ (Table S3). Only the length of the pelvic fin had a low but non-significant phylogenetic signal (Pagel's $\quad \lambda=0.951, \quad P=0.543 ; \quad$ Blomberg's $\mathrm{K}=0.788, P=0.087$ ). Thus, while ancestral state reconstruction showed that sexual dimorphism in the most general trends (identified by two-way ANOVA analyses) were also present in the most recent common ancestor (Fig. 4, Fig. S2), species-specific patterns were clearly not related to phylogeny. For example, closely related species often had a clearly different magnitude of sexual dimorphism (e.g. the sister species T. flavomaculatus and T. grubii, T. arcticus and T. baicalolenensis). This indicates that trends of sexual dimorphism are not more similar among closely related species than to distantly related relatives. While some species, such as T. baicalensis and T. baicalolenensis generally tend to have a high degree of intersexual variability, others such as T. brevirostris and $T$. burejensis, only show slight differences between the sexes or exhibit contrasting patterns to the general trends observed (Figs. 3, S1).
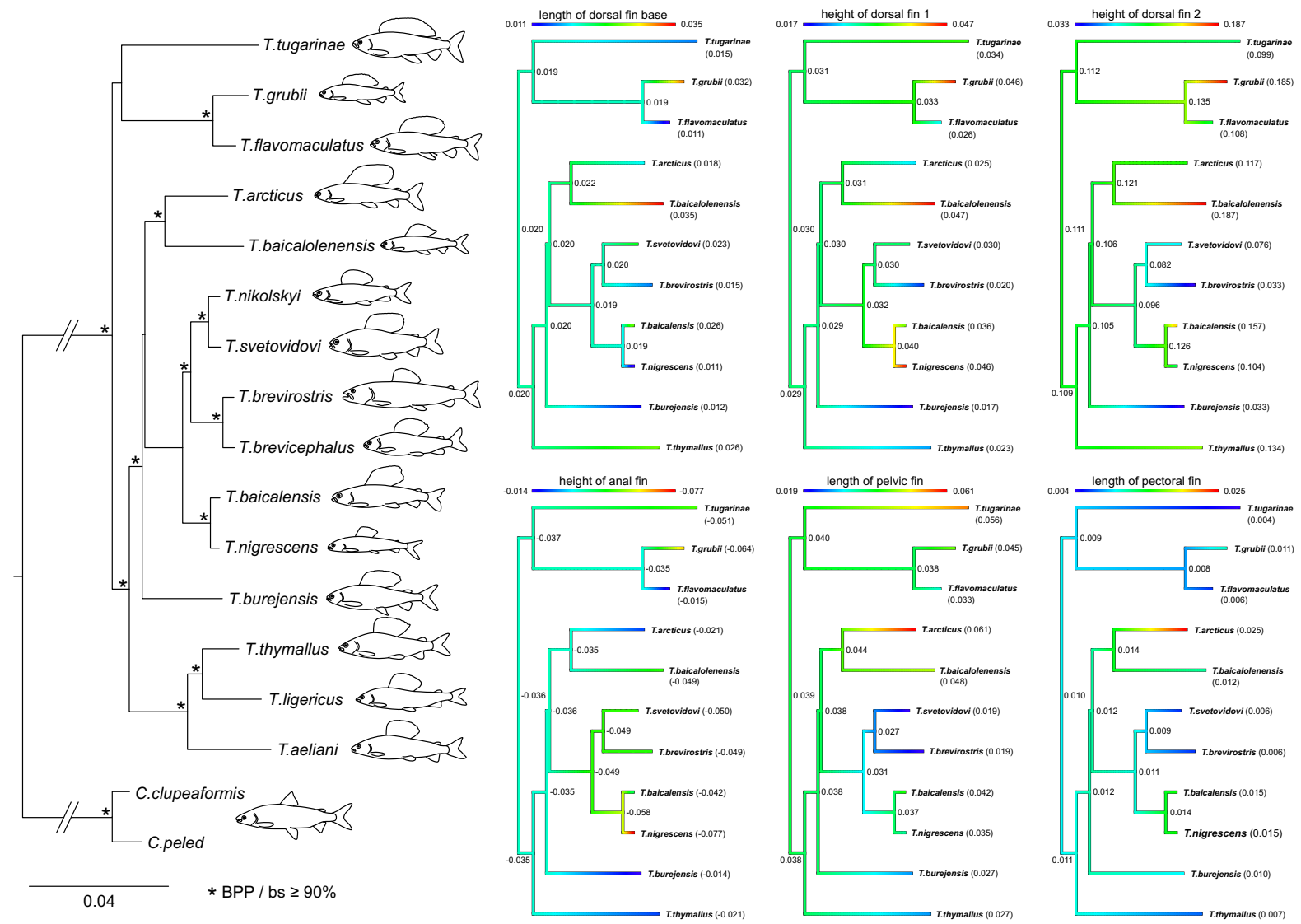

Fig. 4 Phylogenetic reconstruction of Thymallus species based on whole mitochondrial genomes, and ancestral state reconstruction of the degree of sexual dimorphism in the most uniform sexually dimorphic traits of the dorsal, anal, pelvic and pectoral fins $($ red $=$ most dimorphic, blue $=$ least dimorphic $)$.
Thymallus aeliani, T. brevicephalus, T. ligericus, and $T$. nikolskyi were excluded from ancestral state reconstruction due to missing morphological data. Negative values indicate a female-biased trait 
Review of sexual dimorphism in morphometric traits across Salmonidae

We reviewed 56 publications describing sexual dimorphism in morphometric traits among salmonid species (Table 3). The majority of these studies $(n=43)$ were based on the measurement of linear morphometric traits, while six used geometric morphometrics, and seven studies were descriptive and based on visual examination. A comparatively large number of these studies $(\mathrm{n}=19)$ targeted anadromous (mostly semelparous) species of the genus Oncorhynchus. Overall, only a small percentage (11\%) of the large number of salmonid species $(\mathrm{n}=247)$, listed as valid species in Fricke et al. (2021), has been explicitly investigated for sexual dimorphism in external morphometric traits. Although this problem may be overstated due to recent taxonomic inflation (e.g. Isaac et al. 2004), whole genera have apparently been ignored as no specific studies on sexual dimorphism in morphometric traits were found for the genera Brachymystax, Hucho, Parahucho and Stenodus. Among the species analysed, the most general traits of sexual dimorphism across different genera were:

\section{Length of the jaws and snout}

The secondary sexual development of the male jaws (to a lesser extent also present in females), has been reported from several species in the subfamily Salmoninae. The transformation of the jaws (and the elongation of the snout) during the breeding period tends to be most characteristic for semelparous Oncorhynchus (upper jaw), and iteroparous Salmo and Salvelinus (lower jaw) (Table 3). A modification of the upper and/or lower jaw during the reproductive period has not been reported in either Coregoninae or Thymallinae.

\section{Length and depth of the head}

The head tends to be generally more robust in male Salmoninae. In Coregoninae and Thymallinae, dimensions of the head appear to be more sexually monomorphic, though observations by Nikulina and Polyaeva (2020) would suggest a larger head in female Coregonus sardinella.
Length and height of the dorsal fin

Sexual dimorphism in length and height dimensions of the dorsal fin and its base-length are usually malebiased and reported from species in Oncorhynchus, Salmo, Coregonus, Prosopium and Thymallus. Exceptions of female-biased dimensions in the dorsal fin may exist such as in C. sardinella (Table 3).

\section{Size of the adipose fin}

The adipose fin tends to be generally larger (height and length dimensions) in male Oncorhynchus, Salmo, and Salvelinus (Table 3), a trend that appears to be consistent across multiple Salmo species and not restricted to the spawning season (compare to data in Delling and Doardio 2005; Turan et al. 2011, 2012). Data of multiple Coregonus species in alpine lakes would suggest sexual monomorphism in this trait (Selz et al. 2020). Among Thymallinae, intersexual variability in the size of the adipose fin has not been investigated.

\section{Height of the anal fin}

The height of the anal fin was found to be femalebiased in several species of Oncorhynchus, Salmo and Thymallus (Table 3). Morphological studies on European, Eurasian, and North African Salmo species suggest great interspecific variability in this character and a greater height of the anal fin in males of some species (e.g. Turan et al. 2011, 2012; Doadrio et al. 2015). Observations from Coregonus and Prosopoum may suggest sexual monomorphism in this trait or a greater height of the anal fin in male Coregoninae (Table 3).

\section{Length of the paired pelvic and pectoral fins}

The pelvic and pectoral fins were found to be commonly longer in males of species in Oncorhynchus, Salmo, Salvelinus, Coregonus, Prosopium and Thymallus; a trend that appears most consistent in the subfamilies Coregoninae and Thymallinae (Table 3).

\section{Size of breeding tubercles}

Breeding tubercles are known only from iteroparous species. They are most characteristic for Coregoninae 
Table 3 Sexually dimorphic external morphometric traits in Salmonidae

\begin{tabular}{|c|c|c|c|c|c|c|}
\hline Subfamily & Genus & Species & Parity & Male-biased & Female-biased & Reference \\
\hline \multirow[t]{6}{*}{ Salmoninae } & \multirow[t]{6}{*}{ Oncorhynchus } & $\begin{array}{l}\text { gorbuscha } \\
\quad \text { (Pink salmon) }\end{array}$ & Semelparous & $\begin{array}{l}\text { Upper jaw length*, } \\
\text { head length*, } \\
\text { head width, body } \\
\text { depth, caudal } \\
\text { peduncle depth*, } \\
\text { dorsal fin base } \\
\text { length*, adipose } \\
\text { fin length*, anal } \\
\text { fin base length* }\end{array}$ & Anal fin height & $\begin{array}{l}\text { Davidson (1935), } \\
\text { Beacham and } \\
\text { Murray } \\
\text { (1983, 1985, 1986), } \\
\text { Beacham et al. } \\
\text { (1988), Zhivotovsky } \\
\text { and Kim (2015) }\end{array}$ \\
\hline & & $\begin{array}{l}\text { keta (Chum } \\
\text { salmon) }\end{array}$ & Semelparous & $\begin{array}{l}\text { Snout length*, } \\
\text { upper jaw } \\
\text { length*, head } \\
\text { length*, } \\
\text { postorbital head } \\
\text { length*, body } \\
\text { depth*, caudal } \\
\text { peduncle depth*, } \\
\text { prepelvic } \\
\text { length*, dorsal } \\
\text { fin height*, } \\
\text { dorsal fin base } \\
\text { length*, adipose } \\
\text { fin height*, } \\
\text { adipose fin } \\
\text { length* }\end{array}$ & $\begin{array}{l}\text { Horizontal eye } \\
\text { diameter*, anal } \\
\text { fin height*, anal } \\
\text { fin base length* }\end{array}$ & $\begin{array}{l}\text { Beacham and Murray } \\
(1983,1985,1987), \\
\text { Beacham (1984), } \\
\text { Myoung et al. } \\
(1993)^{\mathrm{a}}\end{array}$ \\
\hline & & $\begin{array}{l}\text { kisutch (Coho } \\
\text { salmon) }\end{array}$ & Semelparous & $\begin{array}{l}\text { Snout length*, } \\
\text { upper jaw } \\
\text { length*, tooth } \\
\text { length, body } \\
\text { depth*, dorsal fin } \\
\text { height*, adipose } \\
\text { fin length*, } \\
\text { pelvic fin } \\
\text { length*, pectoral } \\
\text { fin lenght* }\end{array}$ & $\begin{array}{l}\text { Caudal peduncle } \\
\text { depth*, anal fin } \\
\text { height*, anal fin } \\
\text { base length* }\end{array}$ & $\begin{array}{l}\text { Shapovalov and Taft } \\
\text { (1954), Beacham } \\
\text { and Murray } \\
\text { (1983, 1986), } \\
\text { Fleming and Gross } \\
\text { (1994) }\end{array}$ \\
\hline & & $\begin{array}{l}\text { mykiss } \\
\quad \text { (Steelhead } \\
\text { trout) }\end{array}$ & Iteroparous & $\begin{array}{l}\text { Jaw length, tooth } \\
\text { length, body } \\
\text { depth }\end{array}$ & & $\begin{array}{l}\text { Shapovalov and Taft } \\
\text { (1954) }\end{array}$ \\
\hline & & $\begin{array}{l}\text { nerka (Sockeye } \\
\text { salmon) }\end{array}$ & Semelparous & $\begin{array}{l}\text { Snout length, upper } \\
\text { jaw length*, } \\
\text { tooth length, } \\
\text { body depth, } \\
\text { caudal peduncle } \\
\text { depth, adipose fin } \\
\text { length* }\end{array}$ & & $\begin{array}{l}\text { Beacham and Murray } \\
\text { (1983, 1986), Quinn } \\
\text { and Foote (1994), } \\
\text { Hendry and Berg } \\
\text { (1999), Johnson } \\
\text { et al. (2006), Oke } \\
\text { et al. (2019) }\end{array}$ \\
\hline & & $\begin{array}{l}\text { nerka } \\
\quad \text { (Kokanee } \\
\text { salmon) }\end{array}$ & Semelparous & $\begin{array}{l}\text { Snout length*, jaw } \\
\text { length*, tooth } \\
\text { length, body } \\
\text { depth*, caudal fin } \\
\text { height, pelvic fin } \\
\text { length*, pectoral } \\
\text { fin length* }\end{array}$ & $\begin{array}{l}\text { Anal fin height*, } \\
\text { anal fin base } \\
\text { length* }\end{array}$ & $\begin{array}{l}\text { Ricker (1938), } \\
\text { Winans et al. (2003), } \\
\text { Thorn and Morbey } \\
\text { (2016) }\end{array}$ \\
\hline
\end{tabular}


Table 3 continued

\begin{tabular}{|c|c|c|c|c|c|c|}
\hline Subfamily & Genus & Species & Parity & Male-biased & Female-biased & Reference \\
\hline & & $\begin{array}{l}\text { tshawytscha } \\
\text { (Chinook } \\
\text { salmon) }\end{array}$ & Semelparous & $\begin{array}{l}\text { Snout length*, } \\
\text { upper jaw } \\
\text { length*, head } \\
\text { length*, adipose } \\
\text { fin length*, } \\
\text { adipose fin } \\
\text { height* }\end{array}$ & & $\begin{array}{l}\text { Beacham and Murray } \\
(1983,1986), \text { Merz } \\
\text { and Merz (2004) }\end{array}$ \\
\hline & \multirow[t]{4}{*}{ Salmo } & fahrettini & Iteroparous & $\begin{array}{l}\text { Upper jaw length, } \\
\text { mouth gape } \\
\text { length, adipose } \\
\text { fin base length }\end{array}$ & & Turan et al. (2020) \\
\hline & & kottelati & Iteroparous & $\begin{array}{l}\text { Upper jaw length, } \\
\text { mouth gape } \\
\text { length, mouth } \\
\text { gape width, head } \\
\text { length }\end{array}$ & & Turan et al. (2014) \\
\hline & & $\begin{array}{l}\text { salar (Atlantic } \\
\text { salmon) }\end{array}$ & Iteroparous & $\begin{array}{l}\text { Jaw length, adipose } \\
\text { fin size* }\end{array}$ & & $\begin{array}{l}\text { Tchernavin (1944), } \\
\text { Næsje et al. (1988), } \\
\text { Järvi (1990) }\end{array}$ \\
\hline & & $\begin{array}{l}\text { trutta (Brown } \\
\text { trout) }\end{array}$ & Iteroparous & $\begin{array}{l}\text { Upper jaw length, } \\
\text { head length*, } \\
\text { body depth, } \\
\text { dorsal fin height, } \\
\text { adipose fin length }\end{array}$ & $\begin{array}{l}\text { Abdomen length*, } \\
\text { predorsal length, } \\
\text { pectoral-pelvic } \\
\text { distance }\end{array}$ & $\begin{array}{l}\text { Reyes-Gavilán et al. } \\
\text { (1997), Monet et al. } \\
\text { (2006) }\end{array}$ \\
\hline & \multirow[t]{4}{*}{ Salvelinus } & $\begin{array}{l}\text { alpinus (Arctic } \\
\text { char) }\end{array}$ & Iteroparous & $\begin{array}{l}\text { Mouth size*, head } \\
\text { length*, head } \\
\text { depth*, body } \\
\text { depth*, pectoral } \\
\text { fin length* }\end{array}$ & & Janhunen et al. (2009) \\
\hline & & $\begin{array}{l}\text { confluentus } \\
\text { (Bull trout) }\end{array}$ & Iteroparous & $\begin{array}{l}\text { Head length, } \\
\text { adipose fin height }\end{array}$ & & $\begin{array}{l}\text { McPhail and Murray } \\
\text { (1979, seen in } \\
\text { McPhail and Baxter } \\
\text { (1996)), Nitychoruk } \\
\text { et al. (2013) }\end{array}$ \\
\hline & & $\begin{array}{l}\text { fontinalis } \\
\qquad \text { (Brook trout) }\end{array}$ & Iteroparous & $\begin{array}{l}\text { Snout length, lower } \\
\text { jaw length, } \\
\text { mouth width, } \\
\text { head length, head } \\
\text { depth, pelvic fin } \\
\text { length, pectoral } \\
\text { fin length }\end{array}$ & Body width & $\begin{array}{l}\text { Willson (1997), } \\
\text { Proulx and Magnan } \\
\text { (2004), Kazyak et al. } \\
\text { (2013) }\end{array}$ \\
\hline & & $\begin{array}{l}\text { malma (Dolly } \\
\text { Varden trout) }\end{array}$ & Iteroparous & $\begin{array}{l}\text { Snout length, body } \\
\text { depth, adipose fin } \\
\text { height }\end{array}$ & & $\begin{array}{l}\text { McPhail and Murray } \\
(1979, \text { seen in } \\
\text { Beacham and } \\
\text { Murray (1983)), } \\
\text { Yamamoto et al. } \\
\text { (2017) }\end{array}$ \\
\hline Coregoninae & Coregonus & artedi (Cisco) & Iteroparous & $\begin{array}{l}\text { Dorsal fin length, } \\
\text { pectoral fin } \\
\text { length, anal fin } \\
\text { length }\end{array}$ & & Jacobson et al. (2020) \\
\hline
\end{tabular}


Table 3 continued

\begin{tabular}{|c|c|c|c|c|c|c|}
\hline Subfamily & Genus & Species & Parity & Male-biased & Female-biased & Reference \\
\hline & & $\begin{array}{l}\text { clupeaformis } \\
\text { (Lake } \\
\text { whitefish) }\end{array}$ & Iteroparous & $\begin{array}{l}\text { Upper jaw length*, } \\
\text { pelvic fin } \\
\text { length*, pectoral } \\
\text { fin length* }\end{array}$ & & $\begin{array}{l}\text { Casselman and } \\
\text { Schulte-Hostedde } \\
(2004)\end{array}$ \\
\hline & & $\begin{array}{l}\text { lavaretus } \\
\quad \text { (Lavaret) }\end{array}$ & Iteroparous & $\begin{array}{l}\text { Caudal peduncle } \\
\text { width*, anal fin } \\
\text { base length*, } \\
\text { pelvic fin } \\
\text { length*, pectoral } \\
\text { fin length* }\end{array}$ & $\begin{array}{l}\text { Predorsal length*, } \\
\text { prepelvic } \\
\text { length*, pectoral- } \\
\text { pelvic distance*, } \\
\text { body with }\end{array}$ & Heese (1987) \\
\hline & & peled (Peled) & Iteroparous & $\begin{array}{l}\text { Horizontal eye } \\
\text { diameter*, } \\
\text { minimum body } \\
\text { depth*, dorsal fin } \\
\text { height*, dorsal } \\
\text { fin length*, anal } \\
\text { fin height* }\end{array}$ & $\begin{array}{l}\text { Pectoral-pelvic } \\
\text { distance* }^{*}\end{array}$ & $\begin{array}{l}\text { Mamcarz and Nowak } \\
(1986)^{b}\end{array}$ \\
\hline & & $\begin{array}{l}\text { sardinella } \\
\quad \text { (Least cisco) }\end{array}$ & Iteroparous & $\begin{array}{l}\text { Interorbital width*, } \\
\text { prepectoral } \\
\text { length* }\end{array}$ & $\begin{array}{l}\text { Head length*, head } \\
\text { width*, head } \\
\text { depth at nape*, } \\
\text { body depth*, } \\
\text { caudal peduncle } \\
\text { length*, dorsal } \\
\text { fin base length*, } \\
\text { dorsal fin } \\
\text { height*, anal fin } \\
\text { base length*, } \\
\text { pectoral fin base } \\
\text { length* }\end{array}$ & $\begin{array}{l}\text { Nikulina and Polyaeva } \\
\text { (2020) }\end{array}$ \\
\hline & & $\begin{array}{l}\text { zugensis } \\
\quad \text { (Albeli) }\end{array}$ & Iteroparous & $\begin{array}{l}\text { Size of breeding } \\
\text { tubercles* }\end{array}$ & & $\begin{array}{l}\text { Wedekind et al. } \\
\text { (2008) }\end{array}$ \\
\hline & Prosopium & $\begin{array}{l}\text { coulteri } \\
\text { (Pygmy } \\
\text { whitefish) }\end{array}$ & Iteroparous & $\begin{array}{l}\text { Dorsal fin height*, } \\
\text { anal fin height*, } \\
\text { pelvic fin } \\
\text { length*, pectoral } \\
\text { fin length* }\end{array}$ & & McCart (1965) \\
\hline & & $\begin{array}{l}\text { cylindraceum } \\
\text { (Round } \\
\text { whitefish) }\end{array}$ & Iteroparous & $\begin{array}{l}\text { Size of breeding } \\
\text { tubercles }\end{array}$ & Abdomen length & Normandeau (1963) \\
\hline Thymallinae & Thymallus & $\begin{array}{l}\text { arcticus (Arctic } \\
\text { grayling) }\end{array}$ & Iteroparous & $\begin{array}{l}\text { Postorbital length*, } \\
\text { head length*, } \\
\text { head depth at } \\
\text { eye*, body } \\
\text { depth*, } \\
\text { postdorsal } \\
\text { distance*, dorsal } \\
\text { fin height*, } \\
\text { dorsal fin base } \\
\text { length*, anal fin } \\
\text { base length*, } \\
\text { pelvic fin } \\
\text { length*, pectoral } \\
\text { fin length* }\end{array}$ & $\begin{array}{l}\text { Horizontal eye } \\
\text { diameter*, } \\
\text { predorsal length, } \\
\text { preanal length*, } \\
\text { pectoral-anal } \\
\text { distance*, anal } \\
\text { fin height* }\end{array}$ & $\begin{array}{l}\text { Rawson (1950), Ward } \\
\text { (1951), Bishop } \\
\text { (1967, 1971), Tack } \\
\text { (1973), Ridder } \\
\text { (1989), Zinovjev } \\
\text { and Bogdanov } \\
\text { (2012), Romanov } \\
\text { (2016) }\end{array}$ \\
\hline
\end{tabular}


Table 3 continued

\begin{tabular}{|c|c|c|c|c|c|c|}
\hline Subfamily & Genus & Species & Parity & Male-biased & Female-biased & Reference \\
\hline & & $\begin{array}{l}\text { flavomaculatus } \\
\text { (Yellow- } \\
\text { spotted } \\
\text { grayling) }\end{array}$ & Iteroparous & $\begin{array}{l}\text { Lower jaw length, } \\
\text { dorsal fin height, } \\
\text { dorsal fin base } \\
\text { length }\end{array}$ & Anal fin height & $\begin{array}{l}\text { Semenchenko }(2005)^{\mathrm{c}} \text {, } \\
\text { Knizhin et al. } \\
(2006 \mathrm{a})\end{array}$ \\
\hline & & $\begin{array}{l}\text { thymallus } \\
\text { (European } \\
\text { grayling) }\end{array}$ & Iteroparous & $\begin{array}{l}\text { Dorsal fin height*, } \\
\text { dorsal fin base } \\
\text { length*, anal fin } \\
\text { base length*, } \\
\text { pelvic fin } \\
\text { length*, pectoral } \\
\text { fin length* }\end{array}$ & Anal fin height & $\begin{array}{l}\text { Magreiter (1951), } \\
\text { Persat (1977), } \\
\text { Zinovjev (2012), } \\
\text { Kucheruk et al. } \\
\text { (2015) }\end{array}$ \\
\hline & & $\begin{array}{l}\text { tugarinae } \\
\text { (Lower-Amur } \\
\text { grayling) }\end{array}$ & Iteroparous & $\begin{array}{l}\text { Dorsal fin height, } \\
\text { anal fin base } \\
\text { length, pelvic fin } \\
\text { length, pectoral } \\
\text { fin length }\end{array}$ & $\begin{array}{l}\text { Lower jaw length, } \\
\text { preanal length, } \\
\text { pectoral-pelvic } \\
\text { distance, anal fin } \\
\text { height }\end{array}$ & Mikheev (2009) \\
\hline
\end{tabular}

Traits reported significant at $P<0.05$ are marked with an *

${ }^{a}$ Myoung et al. (1993) reported a significantly longer postorbital head length in females while Beacham and Murray (1987) reported the character to be male-biased

${ }^{\mathrm{b}}$ Sexual dimorphism in fishes of age $4+$ is reported

${ }^{\mathrm{c}}$ Therein reported as T. arcticus grubii (Samarga River, Prymorsky Territory)

but were also found in individual species of Thymallinae (T. arcticus, Kratt and Smith (1978); T. thymallus, Witkowski (1982)) and Salmoninae (Salvelinus namaycush, Muir et al. (2012)). Size and abundance of breeding tubercles were found to be usually malebiased.

\section{Discussion}

Sexual dimorphism in graylings

Our analyses revealed a suite of morphometric characters that display significant sexual dimorphism across most grayling species, particularly relating to size dimensions of the dorsal, anal, pelvic and pectoral fins. The differences were pronounced, despite the variation in magnitude and the significant species $\mathrm{x}$ sex interaction in our global analysis. Previous studies suggest that the differentiation between the sexes in these characters starts with the beginning of maturity (Ward 1951; Tack 1973; Kratt and Smith 1979) and is then permanently present in adult fishes outside and during the breeding season. Before sexual maturity, these characters may essentially follow similar growth trajectories in males and females (Kratt and Smith 1979). Yet, our data of fishes at reproductive stage I (immature condition; see Sakun and Butskaya (1968)) indicate a largely similar, but often non-significant pattern of sexual dimorphism for the fins (ANCOVA, $P>0.05 ; \mathrm{n}=285$, across 6 species; data not shown).

The general predictions on the different reproductive strategies and energy investments suggest differential selection acting on the sexes (Fleming and Gross 1994), and thus the existence of sexual dimorphism in specific morphometric traits in order to increase reproductive success. In male graylings, these predictions are consistent with the male-biased length and height dimensions of the dorsal, pelvic and pectoral fins. The display of the dorsal and pelvic fins is an integral behavioural element in male-male competition and territorial behaviour during spawning season (Fabricius and Gustafson 1955). Sex-specific differences in these characters have already been described for T. arcticus (Romanov 2016), T. flavomaculatus (Semenchenko 2005), T. tugarinae (Mikheev 2009) and T. thymallus (Persat 1977; Zinovjev 2012; Kucheruk et al. 2015). The pectoral fin is known to 
support swimming stability and manoeuvrability in many fish groups (Bone and Moore 2008) and may be favourable in male-male competition and mate acquisition. However, the most noticeable morphological trait among graylings - the large colourful dorsal finmay not have evolved as a direct consequence of sexspecific selection as the trait is permanently present in both sexes. Thus, the initial driver of this accentuated character, which does not occur in any other salmonid fish, is most probably rooted in natural selection perhaps in the form of intraspecific competition for position in the typically drift-feeding graylings (Fabricius and Gustafson 1955; Hughes and Dill 1990).

In female graylings, the commonly observed female-biased dimorphism in size among other salmonid species (e.g. Tamate and Maekawa 2004; Morbey 2018) is not supported in our analysis, although length dimensions of the abdomen and distances between fins were generally longer in females. However, these differences may be a secondary effect of the position of the fins perhaps in relation to the extended dorsal and anal fin bases in males. The strongest pattern of female-biased dimorphism was evident for the height of the anal fin. Kratt and Smith (1979) reported that the anal fin is used in lateral display, but the lack of iridescent colouration compared to other fins (see Fig. 1) may indicate a reduced visual function. It is more likely that, similar to other gravel spawning salmonids, the anal fin holds a female-specific (mechanistic) function in reproduction (see Thorn and Morbey 2016), related to the female "probing" behaviour (Groot 1996; Esteve 2005) or oviposition. Compared to other gravel spawning salmonid species, however, female graylings do not construct spawning redds or actively cover the eggs with substrate after fertilization (Fabricius and Gustafson 1955). Instead, the eggs are buried into the substrate by the characteristic spawning behaviour, whereby the caudal region of the female is forced into the porous gravel substrate by vigorous quivering of both sexes and tail flapping of the male (Kratt and Smith 1980). This graylingspecific behaviour may also be key to understanding the observed sexual dimorphism in the caudal region, which includes a deeper caudal peduncle and an elongated length of the anal fin base in males.

An interesting finding of our study is that the extent of sex-specific differences in the general traits is not equal across the genus. The fact that these differences do not have a significant phylogenetic signal would seem to support a differential strength of intrasexual selection across species. Among the few species that showed weaker or a lack of pronounced sexual dimorphism, T. brevirostris from the species poor (i.e. impoverished ichthyofauna; Kottelat (2006)) Altai region of Western Mongolia stands out. This species has comparatively small trait sizes for the fins and generally shows only weak differences in morphometric characters between the sexes. Besides $T$. nigrescens, it is the only species in our data set where in both sexes the greatest height of the dorsal fin is in its anterior part, which does not only affect the shape of the fin (see Knizhin et al. 2008a: Fig. 3), but likely also its display function as the extended posterior part is usually the most colourful region. In contrast, $T$. burejensis, endemic to the Bureya River, a tributary of the Amur River in the Russian Far East, is characterized by having large dorsal, anal, pelvic and pectoral fins in both sexes but significant sexual dimorphism only in the pelvic fin. Thymallus burejensis further contrasts with $T$. brevirostris as it occurs in sympatry with up to three other grayling species (T. baicalolenensis, T. grubii and T. tugarinae; see Antonov (2004); Knizhin et al. (2004)). This raises the possibility that the unique combination of sex-specific attributes reflects past competition (sensu Connell 1980) among sympatric species, supporting species recognition (i.e. distinction between con- and heterospecific individuals) and thus may help to avoid hybridization.

Review of sexual dimorphism in morphometric traits across Salmonidae

Previous studies have shown that sexual dimorphism in salmonids is primarily driven by breeding competition (Fleming and Reynolds 2004). Other factors such as life history tactics (e.g. early maturation) (Koseki and Maekawa 2000) or habitat characteristics (Oke et al. 2019) can have a profound effect on the development and/or expression of sexually dimorphic traits, which underlines the intraspecific (amongpopulation) variability and facultative nature of sexual dimorphism in this group. By reviewing the collective evidence of the factors responsible for trait-specific sexual dimorphism, patterns emerge supporting links between reproductive behaviour or particular environmental conditions and specific morphometric 
character development associated with sex. The reduced taxonomic coverage among existing studies on sexual dimorphism in salmonids limits evolutionary interpretations, but our review nonetheless expands support for a number of assumptions that have been made for single taxa or genera in the past.

Sexual dimorphism is present in all subfamilies of salmonids but the specific traits or patterns of expression differ among groups. In Thymallinae, intersexual variability in morphometric traits is primarily associated with length and height attributes of the fins, although these characters are subject to sexual dimorphism in Coregoninae and Salmoninae as well. The height or length of the dorsal, adipose, pelvic and pectoral fins are male-biased in multiple genera/ species, and were found to play a role in behaviours related to display (e.g. Fabricius and Gustafson 1955; Esteve et al. 2009a; Muir et al. 2012) and female choice (Järvi 1990) but are apparently not so energetically costly as to make them facultative and dependent on life history. Interestingly, the height of the anal fin is the only fin-specific character that shows frequent female-biased dimorphism in gravel spawning Thymallinae and Salmoninae but appears to be monomorphic in the open substrate spawning Coregoninae. Thus, this female-biased trait may have evolved in response to selection pressure on females, related to a mechanistic or sensory function involving oviposition or selection of a suitable spawning habitat (Thorn and Morbey 2016) in order to increase offspring survival. However, the height and shape (see Gruchy and Vladykov 1968) of the anal fin have not yet been investigated in several species, and data on Brachymystax suggest that both sharp- and bluntsnouted lenok are sexually monomorphic in the height of the anal fin (Alekseyev S., unpublished data).

The characteristic transformation of the jaws and snout is limited to Salmoninae, but absent from the basal genera Brachymystax and Hucho (Esteve and McLennan (2008); Esteve et al. (2009b)), and apparently reduced or absent in Parahucho (Esteve et al. 2009a). Thus, these traits may represent a derived set of characters possibly related to the intense breeding competition in Salmoninae. Interestingly, the greatest expression of sexual dimorphism in jaws and snout is exhibited in anadromous and primarily semelparous species (absent in precocious parr; Koseki and Maekawa (2000)), life history strategies that presumably allow more energy to be invested in such asymmetric growth (Fleming and Reynolds 2004). This contrasts somewhat with anadromous $O$. mykiss (Steelhead trout); a species that shows comparatively little dimorphism in the jaws. However, although the species is iteroparous only a rather small percentage of anadromous individuals manage to breed a second time (10\% (0.6-31.3\%) in Fleming (1998); $2.4 \%$ in Christie et al. (2018)). The fact that another iteroparous anadromous salmonid, Salmo salar, exhibits pronounced sexual dimorphism in the lower jaw, as well as a low frequency of repeat spawning with a mean of $11 \%$ (0.7-42.5\%; Fleming (1998)), suggests a mechanistic relationship between anadromous behaviour or (facultative) semelparity and the development of sexual dimorphism at the level of the individual as opposed to a fixed population or species-specific trait.

Compared to Salmoninae and Thymallinae, species in Coregoninae generally exhibit a low degree of sexual dimorphism (Willson 1997). This may be rooted in the fact that Coregoninae contrast sharply in a range of reproductive behaviours compared to other salmonids. For example, Coregoninae are open substrate spawners, exhibit reduced intrasexual competition for access to mates and commonly spawn at night (Fabricius and Lindroth 1954; Karjalainen and Marjomäki 2018), all behavioural traits that are not common in Salmoninae and Thymallinae (Fabricius and Gustafson 1955; Esteve 2005). Thus, spawning behaviour in Coregoninae may favour a different set of (non-visual) signals such as the development of breeding tubercles, which are commonly male biased in size and abundance (Willson 1997). The lacustrine open substrate spawning Salvelinus namaycush (Lake char) with well-described male-biased tubercles (Muir et al. 2012), would support this hypothesis, but there is too little information on tubercles in salmonids in general to draw further conclusions on their prominence and relation to reproductive behaviours and sexual dimorphism.

Overall, it would be revealing to test the effects of environmental conditions vs. common ancestry on trait evolution across a broader phylogenetic range of salmonids with particular focus on species showing diverging life-history tactics or a behavioural repertoire that contrasts with closely related congeners such as observed in S. namaycush (Muir et al. (2012). 
Limitations and future research perspectives

While we think that the general trends of sexual dimorphism in graylings reported in this analysis are robust, a few comments on potential caveats and data limitations are warranted. Multiple populations across the range of some species (e.g. T. arcticus, $T$. baicalensis), contrast with single populations or low sample sizes of some others (e.g. T. nigrescens, $T$. svetovidovi). Thus, some species-specific results may not capture the natural range of variability that is present. Furthermore, the size range analysed does not capture the entire range of sexually mature fish, especially for those species with lower sample sizes. This may be important because the assumed allometric growth component of morphometric traits is likely to lead to a higher degree of dimorphism with age, a variable that we could not assess directly due to the limitation of insufficient sample sizes across multiple age-classes. Lastly, our analyses rely on linear morphometric characters only, without evaluating dichromatism or shape dimorphism, and thus the full scope of sexual dimorphism is assumed to be underestimated. We therefore recognize specific areas of research that could further clarify the patterns and hypotheses concerning the evolution of sexual dimorphism in graylings.

a. The allometric growth component in morphometric traits could be investigated directly for both males and females, perhaps most simply using hatchery-reared populations and the measurement of individuals across their entire life-cycle (following an ontogenetic approach). These studies could provide direct evidence for the secondary sexual development of specific morphological traits and may also include shape dimorphism (geometric morphometrics) to capture a broader extent of intersexual morphological variability. Moreover, such studies could clarify to what extent sexual dimorphism is related to age and growth.

b. The large colourful dorsal fin in graylings has long been suggested to play a key role in reproductive behaviour (Fabricius and Gustafson 1955) and its species-specific colouration pattern (Knizhin 2009) raises the question of species recognition. The recognition of potential conspecific mates may be more important for those species living in sympatry with congeners, as this could help maintain reproductive isolation. It is, however, unclear if and to what extent graylings actively choose mates based on visual traits and more generally what mechanisms may underlie species recognition and mate choice in graylings. In other salmonid species, mate choice appears to be quite common where several sexually dimorphic traits such as the adipose fin in Oncorhynchus and Salmo (Beacham and Murray 1983; Järvi 1990), the kype in Salmo (Perry et al. 2019) or the breeding tubercles in Coregonus (Wedekind et al. 2008) are thought to be, at least partly, subject to female choice and/or serve a function in displaying status.

c. The clarification of which morphological characters are more driven by natural vs. sexual selection as well as the relevance of intra- vs. interspecific competition can be investigated by research on contact zones, such as in the Amur drainage, where at least three if not four grayling species can be found in sympatry (Antonov 2004; Knizhin et al. 2004; Weiss et al. 2020, 2021). In these zones, our sample sizes were limited for some species, and the spectrum of investigated characters could be expanded to include both coloration and shape, if not also differential gene expression that may be mechanistically driving these patterns. Such studies would also benefit from more detailed behavioural data, especially on the spatiotemporal distribution of spawning, as well as both the accentuation and display of body and fin colouration during the entire reproduction period. Likewise, genome-wide sequencing and expression studies can help identify sex-biased gene expression (e.g. Sharma et al. 2014) and alleles (Mohammed et al. 2019), which will foster the understanding of the mechanisms that maintain reproductive isolation.

d. In addition to contact zones, several widespread species, such as T. arcticus, T. baicalensis, $T$. baicalolenensis and T. grubii, which are found in diverse habitats either in sympatry with other grayling species or alone (Weiss et al. 2021), could be investigated specifically for potential morphological (sexually dimorphic) patterns that change based on habitat or the presence or absence of congeners. Thus far, Weiss et al. (2020) touched on the morphological differences within and 
between populations of $T$. baicalolenensis across three different major drainage systems (Amur, Lena, Yenisei), and the likelihood that these differences are driven by different selection mechanisms, potentially including ecological niche partitioning in one drainage, but interspecific competition or its avoidance in another drainage.

More generally, some of our observations can be extended to other genera in Salmonidae, where relatively little is known about general patterns of sexual dimorphism across multiple species and different habitats. We assume that both population and species-specific patterns of sexual dimorphism are relevant for long-term population viability. Thus, we should recognize that our increased knowledge of sexual dimorphism and the underlying evolutionary processes clearly contribute to the growing consensus that the management of salmonid fish populations should aim to avoid using artificial rearing and stocking to supplement populations and above all, inter-basin transfers, whether involving conspecific or congeneric material (Laikre et al. 2010; Rand et al. 2012; Weiss et al. 2013). In areas where such crossbasin transfers have already occurred, and extensive hybridization exists between divergent lineages, such as between $T$. thymallus and T. aeliani in much of the original range of the latter species (Meraner et al. 2014), it would be revealing to examine sexual dimorphism in populations showing introgression and see whether or not the patterns of trait divergence conform to the general patterns of sexual dimorphism observed in the present study.

Acknowledgements The data set presented herein was established by the late I. Knizhin and represents the most comprehensive and detailed collection of morphological information on grayling (Thymallus) species to date. We express our deep gratitude for the help in collecting materials to the inspectors of the Bureinsky Reserve V. Shichanin, P. Sarychev and G. Taranik. We also thank C. Ratschan (EZB) for providing photographs used in the present study, S. Alekseyev (Russian Academy of Sciences) for sharing information on Brachymystax, and K. Sefc (University of Graz) and N. Bogutskaya (Natural History Museum, Vienna) for valuable support to the study. Two anonymous reviewers provided constructive comments on an earlier version of the manuscript. The present work was supported by a grant from the Doctoral Academy Graz, Ecology and Evolution in Changing Environments (EECE) of the University Graz to GKE.
Author contributions Conceived and coordinated the study: GKE, SJW. Analysed the data: GKE. Contributed data and field observations: AA. Wrote the first draft of the paper: GKE, SJW. All three authors contributed equally to the improvement of the manuscript.

Funding Open access funding provided by University of Graz. Doctoral Academy Graz-Ecology and Evolution in Changing Environments (EECE-consortium) of the University of Graz.

Data availability Data are available from the corresponding author upon reasonable request.

\section{Declarations}

Conflict of interest The authors declare no conflict of interest.

Ethical approval In the present study, a data set of morphological characters was analysed but no direct studies on animals were performed by any of the authors.

Open Access This article is licensed under a Creative Commons Attribution 4.0 International License, which permits use, sharing, adaptation, distribution and reproduction in any medium or format, as long as you give appropriate credit to the original author(s) and the source, provide a link to the Creative Commons licence, and indicate if changes were made. The images or other third party material in this article are included in the article's Creative Commons licence, unless indicated otherwise in a credit line to the material. If material is not included in the article's Creative Commons licence and your intended use is not permitted by statutory regulation or exceeds the permitted use, you will need to obtain permission directly from the copyright holder. To view a copy of this licence, visit http://creativecommons.org/licenses/by/4.0/.

\section{References}

Agha M, Ennen JR, Nowakowski AJ, Lovich JE, Sweat SC, Todd BD (2017) Macroecological patterns of sexual size dimorphism in turtles of the world. $J$ Evol Biol 31:336-345. https://doi.org/10.1111/jeb.13223

Andersson M (1994) Sexual selection. Princeton University Press, New Jersey

Antonov AL (2004) A new species of grayling Thymallus burejensis sp. nov. (Thymallidae) from the Amur Basin. J Ichthyol 44:401-411

Beacham TD (1984) Age and morphology of chum salmon in southern British Columbia. Trans Am Fish Soc 113:727-736. https://doi.org/10.1577/15488659(1984)113\%3c727:AAMOCS\%3e2.0.CO;2

Beacham TD, Murray CB (1983) Sexual dimorphism in the adipose fin of Pacific Salmon (Oncorhynchus). Can J Fish Aquat Sci 40:2019-2024. https://doi.org/10.1139/f83-231

Beacham TD, Murray CB (1985) Variation in length and body depth of pink salmon (Oncorhynchus gorbuscha) and 
Chum Salmon (O. keta) in Southern British Columbia. Can J Fish Aquat Sci 42:312-319. https://doi.org/10.1139/f85040

Beacham TD, Murray CB (1986) Sexual dimorphism in length of upper jaw and adipose fin of immature and maturing pacific salmon (Oncorhynchus). Aquaculture 58:269-276. https://doi.org/10.1016/0044-8486(86)90092-X

Beacham TD, Murray CB (1987) Adaptive variation in body sine, age, morphology, egg size, and developmental biology of chum salmon (Oncorhynchers keta) in British Columbia. Can J Fish Aquat Sci 44:244-261. https://doi. org/10.1139/f87-034

Beacham TD, Withler RE, Murray CB, Barner LW (1988) Variation in body size, morphology, egg size, and biochemical genetics of pink salmon in British Columbia. Trans Am Fish Soc 117:109-126. https://doi.org/10.1577/ 1548-8659(1988)117\%3c0109:VIBSME\%3e2.3.CO;2

Beauchamp DA (1990) Movements, habitat use, and spawning strategies of arctic grayling in a subalpine lake tributary. Northwest Sci 64:195-207

Berns CM, Adams DC (2012) Becoming different but staying alike: patterns of sexual size and shape dimorphism in bills of hummingbirds. Evol Biol 40:246-260. https://doi.org/ 10.1007/s11692-012-9206-3

Bishop FG (1971) Observations on spawning habits and fecundity of the arctic grayling. The Progressive FishCulturist 33:12-19. https://doi.org/10.1577/15488640(1971)33[12:OOSHAF]2.0.CO;2

Bishop FG (1967) The biology of the Arctic grayling, Thymallus arcticus (Pallas), in Great Slave Lake. Master thesis, Department of Zoology, University of Alberta, Edmonton

Blomberg SP, Garland T Jr, Ives AR (2003) Testing for phylogenetic signal in comparative data: behavioral traits are more labile. Evolution 57:717-745. https://doi.org/10. 1111/j.0014-3820.2003.tb00285.x

Bone Q, Moore RH (2008) Biology of fishes, 3rd edn. Taylor \& Francis Group, New York, p 478

Campbell MA, Buser TJ, Alfaro ME, López JA (2020) Addressing incomplete lineage sorting and paralogy in the inference of uncertain salmonid phylogenetic relationships. PeerJ 8:e9389. https://doi.org/10.7717/peerj.9389

Casselman SJ, Schulte-Hostedde AI (2004) Reproductive roles predict sexual dimorphism in internal and external morphology of lake whitefish, Coregonus clupeaformis. Ecol Freshw Fish 13:217-222. https://doi.org/10.1111/j.16000633.2004.00053.x

Christie M, McNicklec G, Frenche R, Blouin M (2018) Life history variation is maintained by fitness trade-offs and negative frequency-dependent selection. PNAS 115:4441-4446. https://doi.org/10.1073/pnas.1801779115

Clutton-Brock T (2007) Sexual selection in males and females. Science 318:1882-1885. https://doi.org/10.1126/science. 1133311

Connell JH (1980) Diversity and the coevolution of competitors, or the ghost of competition past. Oikos 35:131-138. https:// doi.org/10.2307/3544421

Cooper IA (2010) Ecology of sexual dimorphism and clinal variation of coloration in a damselfly. Am Nat 176:566-572. https://doi.org/10.1086/656491

Darwin CR (1871) The descent of man and selection in relation to sex. John Murray, London
Davidson FA (1935) The development of the secondary sexual characters in the pink salmon (Oncorhynchus gorbuscha). J Morphol 57:169-183. https://doi.org/10.1002/jmor. 1050570110

Delling B, Doardio I (2005) Systematics of the trouts endemic to Moroccan lakes, with description of a new species (Teleostei: Salmonidae). Ichthyol Explor Freshw 16:49-64

Doadrio I, Perea S, Yahyaoui A (2015) Two new species of Atlantic trout (Actinopterygii, Salmonidae) from Morocco. Graellsia 71:e031. https://doi.org/10.3989/graellsia.2015. v71.142

Esteve M (2005) Observations of spawning behaviour in Salmoninae: Salmo, Oncorhynchus and Salvelinus. Rev Fish Biol Fish 15:1-21. https://doi.org/10.1007/s11160-0057434-7

Esteve M, McLennan DA (2008) Spawning Behavior of Lenok, Brachymystax lenok (Salmoniformes) from the Uur River, Northern Mongolia. J Ichthyol 48:1031-1036. https://doi. org/10.1134/S0032945208110040

Esteve M, McLennan DA, Kawahara M (2009a) Spawning behaviour of Sakhalin taimen, Parahucho perryi, from northern Hokkaido, Japan. Environ Biol Fish 85:265-273. https://doi.org/10.1007/s10641-009-9495-2

Esteve M, Gilroy D, McLennan DA (2009b) Spawning behaviour of taimen (Hucho taimen) from the Uur River, Northern Mongolia. Environ Biol Fish 84:185-189. https:// doi.org/10.1007/s10641-008-9407-x

Fabricius E, Lindroth A (1954) Experimental Observations on the Spawning of Whitefish, Coregonus lavaretus L., in the Stream Aquarium of the Hölle Laboratory at River Indalsälven. Report: Institute of Fresh-water Research, Drottningholm 35:105-112

Fabricius E, Gustafson K-J (1955) Observations on the spawning behaviour of the grayling, Thymallus thymallus (L.). Rep Inst Freshw Res Drottningholm 36:75-103

Fausch KD, White RJ (1981) Competition between brook trout (Salvelinus fontinalis) and brown trout (S. trutta) for positions in a Michigan stream. Can J Fish Aquat Sci 38:1220-1227. https://doi.org/10.1139/f81-164

Fleming IA (1998) Pattern and variability in the breeding system of Atlantic salmon (Salmo salar), with comparisons to other salmonids. Can J Fish Aquat Sci 55:59-76. https:// doi.org/10.1139/d98-009

Fleming IA, Gross MR (1994) Breeding Competition in a Pacific Salmon (Coho: Oncorhynchus kisutch): Measures of Natural and Sexual Selection. Evolution 48:637-657. https://doi.org/10.2307/2410475

Fleming IA, Reynolds JD (2004) Salmonid breeding systems. In: Hendry AP, Stearns SC (eds) Evolution illuminated: Salmon and their relatives. Oxford University Press, Oxford, pp 264-294

Fricke R, Eschmeyer WN, Van der Laan R (eds) (2021) Eschmeyer's catalog of fishes: genera, species, references. http://researcharchive.calacademy.org/research/ ichthyology/catalog/fishcatmain.asp. Electronic version accessed 15 September 2021

Froufe E, Knizhin I, Koskinen MT, Primmer CR, Weiss S (2003) Identification of reproductively isolated lineages of Amur grayling (Thymallus grubii Dybowski 1869): concordance between phenotypic and genetic variation. Mol 
Ecol 12:2345-2355. https://doi.org/10.1046/j.1365-294X. 2003.01901.x

Groot C (1996) Salmonid life histories. In: Pennell W, Bruce A (eds) Principles of salmonid culture. Elsevier, Amsterdam, pp 97-230

Gruchy CG, Vladykov VD (1968) Sexual dimorphism in anal fin of brown Trout, Salmo trutta, and close relatives. J Fish Res Board Can 25:813-815. https://doi.org/10.1139/f68-073

Hedrick AV, Temeles EJ (1989) The evolution of sexual dimorphism in animals: hypotheses and tests. Trends Ecol Evol 4:136-138. https://doi.org/10.1016/01695347(89)90212-7

Heese T (1987) Morphology of two plastic forms of whitefish (Coregonus lavaretus (L.)) occurring in the Pomeranian Bay and Szczecin Lagoon. Acta Ichthyol Piscat 17:3-28

Hendry AP, Berg OK (1999) Secondary sexual characters, energy use, senescence, and the cost of reproduction in sockeye salmon. Can J Zool 77:1663-1675. https://doi.org/ 10.1139/z99-158

Hughes NF (1992) Ranking of feeding positions by drift-feeding arctic grayling Thymallus arcticus in dominance hierarchies. Can J Fish Aguat Sci 49:1994-1998. https://doi.org/ 10.1139/f92-222

Hughes NF, Dill LM (1990) Position choice by drift-feeding salmonids: model and test for Arctic Grayling (Thymallus arcticus) in Subarctic Mountain Streams, Interior Alaska. Can J Fish Aguat Sci 47:2039-2048. https://doi.org/10. 1139/f90-228

Isaac NJB, Mallet J, Mace GM (2004) Taxonomic inflation: its influence on macroecology and conservation. Trends Ecol Evol 19:464-469. https://doi.org/10.1016/j.tree.2004.06. 004

Jacobs A, Carruthers M, Yurchenko A, Gordeeva NV, Alekseyev SS, Hooker O, Leong JS, Minkley DR, Rondeau EB, Koop BF, Adams CE, Elmer KR (2020) Parallelism in ecomorphology and gene expression despite variable evolutionary and genomic backgrounds in a Holarctic fish. PLoS Genet 16:e1008658. https://doi.org/10.1371/journal.pgen. 1008658

Jacobson PC, Zimmer KD, Grow R, Eshenroder RL (2020) Morphological variation of cisco across gradients of lake productivity. Trans Am Fish Soc 149:462-473. https://doi. org/10.1002/tafs.10242

Janhunen M, Peuhkuri N, Piironen J (2009) Morphological variability among three geographically distinct Arctic charr (Salvelinus alpinus L.) populations reared in a common hatchery environment. Ecol Freshw Fish 18:106-116. https://doi.org/10.1111/j.1600-0633.2008.00329.x

Järvi T (1990) The effects of male dominance, secondary sexual characteristics and female mate choice on the mating success of male atlantic salmon Salmo salar. Ethology 84:123-132. https://doi.org/10.1111/j.1439-0310.1990. tb00789.x

Johnson DE (1998) Applied multivariate methods for data analysts. Duxbury Press, University of Michigan

Johnson SP, Carlson SM, Quinn TP (2006) Tooth size and skin thickness in mature sockeye salmon: evidence for habitat constraints and variable investment between the sexes. Ecol Freshw Fish 15:331-338. https://doi.org/10.1111/j. 1600-0633.2006.00175.x
Jonsson B, Jonsson N (2015) Sexual size dimorphism in anadromous brown trout Salmo trutta. J Fish Biol 87:187-193. https://doi.org/10.1111/jfb.12704

Karjalainen J, Marjomäki TJ (2018) Communal pair spawning behaviour of vendace (Coregonus albula) in the dark. Ecol Freshw Fish 27:542-548. https://doi.org/10.1111/eff. 12368

Kazyak DC, Hilderbrand RH, Holloway AE (2013) Rapid visual assessment to determine sex in brook trout. N Am J Fish Manag 33:665-668. https://doi.org/10.1080/02755947. 2013.785998

Knizhin IB, Weiss SJ (2009) A new species of grayling Thymallus svetovidovi sp. nova (Thymallidae) from the Yenisei basin and its position in the genus Thymallus. J Ichthyol 49:1-9. https://doi.org/10.1134/ S0032945209010019

Knizhin IB, Weiss SJ, Antonov AL, Froufe E (2004) Morphological and genetic diversity of Amur Graylings (Thymallus, Thymallidae). J Ichthyol 44:52-69

Knizhin IB, Antonov AL, Weiss SJ (2006a) A new subspecies of the amur grayling Thymallus grubii flavomaculatus ssp. nova (Thymallidae). J Ichthyol 46:555-562. https://doi. org/10.1134/S0032945206080017

Knizhin IB, Kirillov AF, Weiss SJ (2006b) On the diversity and taxonomic status of graylings (Thymallus Thymallidae) from the Lena River. J Ichthyol 46:234-246. https://doi. org/10.1134/S0032945206030039

Knizhin IB, Bogdanov BE, Vasil'eva EA (2006c) Biological and morphological characteristic of the arctic grayling Thymallus arcticus (Thymallidae) from Alpine Lakes of the Basin of the upper reaches of the angara river. J Ichthyol 46:709-721. https://doi.org/10.1134/ S0032945206090037

Knizhin IB, Weiss SJ, Bogdanov BE, Samarina SS, Froufe E (2006d) Finding a new form of the Grayling Thymallus arcticus (Thymallidae) in the Basin of Lake Baikal. J Ichthyol 46:34-43. https://doi.org/10.1134/ S003294520601005X

Knizhin IB, Antonov AL, Safronov SN, Weiss SJ (2007) New species of grayling Thymallus tugarinae sp. nova (Thymallidae) from the Amur River Basin. J Ichthyol 47:123-139. https://doi.org/10.1134/S0032945207020014

Knizhin IB, Weiss SJ, Bogdanov BE, Kopun T, Muzalevskaya OV (2008) Graylings (Thymallidae) of water bodies in western Mongolia: Morphological and genetic diversity. J Ichthyol 48:714-735. https://doi.org/10.1134/ S0032945208090038

Knizhin IB, Weiss SJ, Bogdanov BE, Kopun T (2008b) New data on the distribution of the Upper Lena form of grayling (Thymallidae) in the basin of Lake Baikal and its taxonomic status. J Ichthyol 48:217-223. https://doi.org/10. 1134/S003294520803003X

Knizhin IB (2009) Graylings (Thymallus Cuvier, 1829) of the Holarctic (Systematics, Phylogeography, and Ecological features) $[=$ Хариусы (Thymallus Cuvier, 1829) Голарктики (систематика, филогеография, особенности экологии)]. Dissertation, Severtsov Institute of Ecology and Evolution, Russian Academy of Science (in Russian)

Koseki Y, Maekawa K (2000) Sexual selection on mature male parr of masu salmon (Oncorhynchus masou): does sneaking behavior favor small body size and less-developed 
sexual characters? Behav Ecol Sociobiol 48:211-217. https://doi.org/10.1007/s002650000231

Kottelat M (2006) Fishes of Mongolia: a check-list of the fishes known to occur in Mongolia with comments on systematics and nomenclature. Environment and Social Development Sector, East Asia and Pacific Region, The World Bank, Washington. $103 \mathrm{pp}$

Kratt LF, Smith RJF (1978) Breeding tubercles occur on male and female arctic grayling (Thymallus arcticus). Copeia 1:185-188. https://doi.org/10.2307/1443852

Kratt LF, Smith RJF (1979) Agonistic behaviour of age 0, age 1 and non-breeding adult Arctic grayling Thymallus arcticus (Pallas). J Fish Biol 15:389-404. https://doi.org/10.1111/j. 1095-8649.1979.tb03622.x

Kratt LF, Smith RJF (1980) An analysis of the spawning behaviour of the Arctic grayling Thymallus arcticus (Pallas) with observations on mating success. J Fish Biol 17:661-666. https://doi.org/10.1111/j.1095-8649.1980. tb02799.x

Kucheruk AI, Mruk AI, Kovalenko VO (2015) Morphometric characteristics of European grayling (Thymallus thymallus L.) in Transcarpathian rivers. Scientific reports of NULES of Ukraine

Laikre L, Schwartz MK, Waples RS, Ryman N, GeM Working Group (2010) Compromising genetic diversity in the wild: unmonitored large-scale release of plants and animals. Trends Ecol Evol 25:520-529. https://doi.org/10.1016/j. tree.2010.06.013

Magreiter H (1951) Der Geschlechtsdimorphismus Der Äschen. Österreichs Fischerei 2:28-30 (in German)

Mamcarz A, Nowak M (1986) Rearing of coregonid fishes (Coregonidae) in illuminated lake cages: VI-characteristics of the spawners of whitefish (Coregonus lavaretus L.) and peled (Coregonus peled Gmel.) from cage culture. Aquaculture 55:51-58. https://doi.org/10.1016/00448486(86)90055-4

McCart P (1965) Growth and morphometry of four british columbia populations of pygmy whitefish (Prosopium coulteri). J Fish Res Bd Can 22:1229-1259. https://doi.org/ 10.1139/f65-107

McPhail JD, Baxter JS (1996) A Review of Bull Trout (Salvelinus confluentus) life-history and habitat use in relation to compensation and improvement opportunities. Fisheries management report No. 104, Univ. Boulevard, Vancouver $39 \mathrm{p}$

McPhail JD, Murray CB (1979) The early life history and ecology of Dolly Varden (Salvelinus malma) in the upper Arrow Lakes. Univ. British Columbia Rep. for British Columbia Hydro, Vancouver, p 113

Meraner A, Cornetti L, Gandolfi A (2014) Defining conservation units in a stocking-induced genetic melting pot: unraveling native and multiple exotic genetic imprints of recent and historical secondary contact in Adriatic grayling. Ecol Evol 4:1313-1327. https://doi.org/10.1002/ece3. 931

Merz JE, Merz WR (2004) Morphological features used to identify Chinook salmon sex during fish passage. Southwest Nat 49:197-202

Mikheev PB (2009) Sexual Dimorphism of Lower Amur Grayling Thymallus tugarinae (Thymallidae). Amurian Zoological J 1:386-391
Mohammed AR, Verbyla KL, Al-Mamun HA, McWilliam S, Evans B, King H, Kube P, Kijas JW (2019) Polygenic and sex specific architecture for two maturation traits in farmed Atlantic salmon. BMC Genom 20:139. https://doi.org/10. 1186/s12864-019-5525-4

Monet G, Uyanik A, Champigneulle A (2006) Geometric morphometrics reveals sexual and genotypic dimorphisms in the brown trout. Aquat Living Resour 19:47-57. https:// doi.org/10.1051/alr:2006004

Morbey YE (2018) Female-biased dimorphism in size and age at maturity is reduced at higher latitudes in lake whitefish Coregonus clupeaformis. J Fish Biol 93:40-46. https://doi. org/10.1111/jfb.13675

Muir AM, Blackie CT, Marsden JE, Krueger CC (2012) Lake charr Salvelinus namaycush spawning behaviour: new field observations and a review of current knowledge. Rev Fish Biol Fish 22:575-593. https://doi.org/10.1007/s11160012-9258-6

Myoung J-G, Hong K-P, Kim Y-U (1993) Morphological study of Oncorhynchus spp. (Pisces: Salmonidae) in Korea- III: sexual dimorphism of chum salmon Oncorhynchus Keta. Korea J Ichthyol 5:85-95

Næsje TF, Hansen LP, Järvi T (1988) Sexual dimorphism in the adipose fin of Atlantic salmon, Salmo salar L. J Evol Biol 33:955-956. https://doi.org/10.1111/j.1095-8649.1988. tb05547.x

Nguyen L-T, Schmidt HA, von Haeseler A, Minh BQ (2015) IQTREE: a fast and effective stochastic algorithm for estimating maximum-likelihood phylogenies. Mol Biol Evol. https://doi.org/10.1093/molbev/msu300

Nikulina YS, Polyaeva KV (2020) Morphology, biology and parasite fauna of the least cisco (Coregonus sardinella) of the Yenisei River. Biosyst Div 28:230-237. https://doi.org/ 10.15421/012030

Nitychoruk JM, Gutowsky LFG, Harrison PM, Hossie TJ, Power M, Cooke SJ (2013) Sexual and seasonal dimorphism in adult adfluvial bull trout (Salvelinus confluentus). Can J Zool 91:480-488. https://doi.org/10.1139/cjz-20120294

Normandeau DA (1963) The Life history of the round whitefish Prosopium cylindraceum (Pallas) of Newfound Lake, New Hampshire. Dissertation, University of New Hampshire $115 \mathrm{p}$

Oke KB, Motivans E, Quinn TP, Hendry AP (2019) Sexual dimorphism modifies habitat-associated divergence: Evidence from beach and creek breeding sockeye salmon. J Evol Biol 32:227-242. https://doi.org/10.1111/jeb.13407

Pagel M (1999) Inferring the historical patterns of biological evolution. Nature 401:877-884. https://doi.org/10.1038/ 44766

Perry WB, Solberg MF, Besnier F, Dyrhovden L, Matre IH, Fjelldal PG, Ayllon F, Creer S, Llewellyn M, Taylor MI, Carvalho G, Glover KA (2019) Evolutionary drivers of kype size in Atlantic salmon (Salmo salar): domestication, age and genetics. Royal Soc Open Sci 6:190021. https:// doi.org/10.1098/rsos.190021

Persat H (1977) Ecologie de l'ombre commun. Bull Fr Piscic 266:11-20. https://doi.org/10.1051/kmae:1977004

Persat H, Mattersdorfer K, Charlat S, Schenelar T, Weiss S (2016) Genetic integrity of the European grayling (Thymallus thymallus) populations within the Vienne River 
drainage basin after five decades of stockings. Cybium 40:7-20. https://doi.org/10.26028/cybium/2016-401-001

Pincheira-Donoso D, Harvey LP, Grattarola F, Jara M, Cotter SC, Tregenza T, Hodgson DJ (2021) The multiple origins of sexual size dimorphism in global amphibians. Global Ecol Biogeogr 30:443-458. https://doi.org/10.1111/geb. 13230

Pravdin IF (1966) Guide on fish study [= Rukovodstvo po izucheniyu ryb]. Pishchevaya Promyshlennost, Moscow (in Russian)

Proulx R, Magnan P (2004) Contribution of phenotypic plasticity and heredity to the trophic polymorphism of lacustrine brook charr (Salvelinus fontinalis M.). Evol Ecol Res 6:503-522

Punzalan D, Hosken DJ (2010) Sexual Dimorphism: Why the Sexes Are (and Are Not) Different. Curr Biol 20:R972R973. https://doi.org/10.1016/j.cub.2010.09.067

Quinn TP, Foote CJ (1994) The effects of body size and sexual dimorphism on the reproductive behaviour of sockeye salmon, Oncorhynchus nerka. Anim Behav 48:751-761. https://doi.org/10.1006/anbe.1994.1300

R Core Team (2021) R: A language and environment for statistical computing. R Foundation for Statistical Computing, Vienna, Austria. Available on internet at https://www. R-project.org/

Rambaut A (2018) FigTree v. 1.4.4. https://github.com/ rambaut/figtree/releases [downloaded January 2019]

Rand PS, Berejikian BA, Bidlack A, Bottom D, Gardner J, Kaeriyama M, Lincoln R, Nagata M, Pearsons TN, Schmidt M, Smoker WW, Weitkamp LA, Zhivotovsky LA (2012) Ecological interactions between wild and hatchery salmonids and key recommendations for research and management actions in selected regions of the North Pacific. Environ Biol Fishes 94:343-358. https://doi.org/ 10.1007/s10641-012-9988-2

Rawson DS (1950) The grayling (Thymallus signifer) in northern Saskatchewan. Can Fish Cult 6:3-10

Revell LJ (2012) Phytools: an R package for phylogenetic comparative biology (and other things). Methods Ecol Evol 3:217-223. https://doi.org/10.1111/j.2041-210X.2011. 00169. $\mathrm{x}$

Reyes-Gavilán FG, Ojanguren AF, Braña F (1997) The ontogenetic development of body segments and sexual dimorphism in brown trout (Salmo trutta L.). Can J Zool 75:651-655. https://doi.org/10.1139/z97-083

Ricker WE (1938) "Residual" and kokanee salmon in Cultus Lake. J Fish Res Board Can 4:192-218

Ridder WP (1989) Age, Length, Sex, and Abundance of Arctic Grayling in the Goodpaster River, 1956 through 1988. Fishery data series No. 94. Alaska Department of Fish and Game Division of Sport Fish Juneau, Alaska

Romanov VI (2016) Morphological Differences of Arctic Grayling Thymallus arcticus (Pallas, 1776) from Lakes in Khatanga River Basin Associated with the Adaptations to the Mountain and Plain Habitats [= Морфологическая изменчивость сибирского хариуса (Thymallus arcticus (Pallas, 1776)) из разнотипных озёр бассейна реки Хатанги (полуостров Таймыр) в связи с адаптациями к горным и равнинным условиям]. Bull Irkutsk State Univ Ser Biol Ecol 18:45-57 (in Russian)
Ruxton GD (2006) The unequal variance t-test is an underused alternative to Student's t-test and the Mann-Whitney U test. Behav Ecol 17:688-690. https://doi.org/10.1093/ beheco/ark016

Sakun OF, Butskaya NA (1968) Determination of Stage of Maturation and Study of Sexual Cycles of Fishes [= Opredelenie stadii zrelosti i izuchenie polovykh tsiklov ryb]. Murmansk: PINRO. (in Russian)

Selz OM, Dönz CJ, Vonlanthen P, Seehausen O (2020) A taxonomic revision of the whitefish of lakes Brienz and Thun, Switzerland, with descriptions of four new species (Teleostei, Coregonidae). ZooKeys 989:79-162. https://doi.org/ 10.3897/zookeys.989.32822

Semenchenko AA (2005) Biological Peculiarities of Arctic Grayling Thymallus arcticus grubii Dybowski of the Samarga River [= Особенности биологии амурского хариуса Thymallus arcticus grubii Dybowski реки Cамарга]. Readings in Memory of Vladimir Yakovlevich Levanidov (Vladimir Ya. Levanidov's Biennial Memorial Meetings) 1:217-228. (in Russian)

Shapovalov L, Taft AC (1954) The life histories of the steelhead rainbow trout (Salmo gairdneri gairdner) and silver salmon (Oncorhynchus kisutch) with special reference to Wadell Creek, California, and recommendations regarding their management. Calif Fish Bull 98

Sharma E, Künstner A, Fraser BA, Zipprich G, Kottler VA, Henz SR, Weigel D, Dreyer C (2014) Transcriptome assemblies for studying sex-biased gene expression in the guppy Poecilia Reticulata. BMC Genom 15:400. https:// doi.org/10.1186/1471-2164-15-400

Shubin PN, Zakharov AB (1984) Hybridization between European Grayling, Thymallus thymallus, and Arctic Grayling, Thymallus arcticus, in the Contact Zone of the Species. J Ichthyol 4:159-163

Sidlauskas BL, Mol JH, Vari RP (2011) Dealing with allometry in linear and geometric morphometrics: a taxonomic case study in the Leporinus cylindriformis group (Characiformes: Anostomidae) with description of a new species from Suriname. J Linn Soc 162:103-130. https://doi.org/ 10.1111/j.1096-3642.2010.00677.x

Siwertsson A, Knudsen R, Adams CE, Præbel K, Amundsen P-A (2013) Parallel and non-parallel morphological divergence among foraging specialists in European whitefish (Coregonus lavaretus). Ecol Evol 3:1590-1602. https://doi.org/10.1002/ece3.562

Svetovidov AN (1936) Euroasian Graylings (Genus Thymallus Cuvier). Trudy Zoologicheskogo Instituta Akademiya Nauk SSSR 3:183-301

Swanson EM, McElhinny TL, Dworkin I, Weldele ML, Glickman SE, Holekamp KE (2013) Ontogeny of sexual size dimorphism in the spotted hyena (Crocuta crocuta). J Mammal 94:1298-1310. https://doi.org/10.1644/12MAMM-A-277.1

Tack SL (1973) Distribution, Abundance, and Natural History of the Arctic Grayling in the Tanana River Drainage. Alaska Department of Fish and Game, Annual Progress Report, 14(R-I)

Tamate T, Maekawa K (2004) Female-biased mortality rate and sexual size dimorphism of migratory masu salmon, Oncorhynchus masou. Ecol Freshw Fish 13:96-103. https:// doi.org/10.1111/j.1600-0633.2004.00043.x 
Tchernavin V (1944) The breeding characters of salmon in relation to their size. Proc Zool Soc Lond 113:206-132. https://doi.org/10.1111/j.1096-3642.1944.tb00845.x

Thorn MW, Morbey YE (2016) Evidence for the secondary sexual development of the anal fin in female kokanee salmon Oncorhynchus nerka. J Fish Biol 88:448-458. https:// doi.org/10.1111/jfb. 12800

Turan D, Kottelat M, Bektaş Y (2011) Salmo tigridis, a new species of trout from the Tigris River, Turkey (Teleostei: Salmonidae). Zootaxa 2993:23-33. https://doi.org/10. 11646/zootaxa.2993.1.2

Turan D, Kottelat M, Engin S (2012) The trouts of the Mediterranean drainages of southern Anatolia, Turkey, with description of three new species (Teleostei: Salmonidae). Ichthyol Explor Freshw 23:219-236

Turan D, Doğan E, Kaya C, Kanyılmaz M (2014) Salmo kottelati, a new species of trout from Alakır Stream, draining to the Mediterranean in southern Anatolia, Turkey (Teleostei, Salmonidae). ZooKeys 462:135-151. https://doi.org/ 10.3897/zookeys.462.8177

Turan D, Kalaycı G, Bektaş Y, Kaya C, Bayçelebi E (2020) A new species of trout from the northern drainages of Euphrates River, Turkey (Salmoniformes: Salmonidae). J Fish Biol 96:1454-1462. https://doi.org/10.1111/jfb. 14321

Ward JC (1951) The biology of the Arctic grayling in the southern Athabaska drainage. M.S. Thesis, Univ. Alberta, Edmonton.

Warton DI, Wright IJ, Falster DS, Westoby M (2006) Bivariate line-fitting methods for allometry. Biol Rev 81:259-291. https://doi.org/10.1017/S1464793106007007

Wedekind C, Evanno G, Urbach D, Jacob A, Müller R (2008) 'Good-genes' and 'compatible-genes' effects in an Alpine whitefish and the information content of breeding tubercles over the course of the spawning season. Genetica 132:199-208. https://doi.org/10.1007/s10709-007-9164-3

Weiss S, Knizhin I, Kirillov A, Froufe E (2006) Phenotypic and genetic differentiation of two major phylogeographical lineages of arctic grayling Thymallus arcticus in the Lena River, and surrounding Arctic drainages. Biol J Linn Soc Lond 88:511-525. https://doi.org/10.1111/j.1095-8312. 2006.00621.x

Weiss S, Knizhin I, Romanov V, Kopun T (2007) Secondary contact between two divergent lineages of grayling Thymallus in the lower Enisey basin and its taxonomic implications. J Fish Biol 71:371-386. https://doi.org/10.1111/j. 1095-8649.2007.01662.x

Weiss SJ, Kopun T, Sušnik Bajec S (2013) Assessing natural and disturbed population structure in European grayling Thymallus thymallus: melding phylogeographic, population genetic and jurisdictional perspectives for conservation planning. J Fish Biol 82:505-521. https://doi.org/10. 1111/jfb.12007

Weiss S, Secci-Petretto G, Antonov A, Froufe E (2020) Multiple species of grayling (Thymallus $\mathrm{sp}$.) found in sympatry in a remote tributary of the Amur River. Zool Scr 49:117-128. https://doi.org/10.1111/zsc.12393
Weiss SJ, Gonçalves DV, Secci-Petretto G, Englmaier GK, Gomes-Dos-Santos A, Denys GPJ, Persat H, Antonov A, Hahn C, Taylor EB, Elsa F (2021) Global systematic diversity, range distributions, conservation and taxonomic assessments of graylings (Teleostei: Salmonidae; Thymallus spp.). Org Divers Evol 21:25-42. https://doi.org/10. 1007/s13127-020-00468-7

Wilhelm G, Handschuh S, Plantl J, Nemeschkal HL (2011) Sexual dimorphism in head structures of the weevil Rhopalapion longirostre (Olivier 1807) (Coleoptera: Curculionoidea): a response to ecological demands of egg deposition. Biol J Linn Soc Lond 104:642-660. https://doi. org/10.1111/j.1095-8312.2011.01751.x

Willson MF (1997) Variation in salmonid life histories: patterns and perspectives. U.S. Department of Agriculture, Forest Service, Pacific Northwest Research Station. 50 p. https:// doi.org/10.2737/PNW-RP-498

Winans GA, Pollard S, Kuligowski DR (2003) Two reproductive life history types of kokanee, Onchorynchus nerka, exhibit multivariate morphometric and protein genetic differentiation. Environ Biol Fish 77:87-100. https://doi. org/10.1023/A:1024401102141

Witkowski A (1982) Occurrence, distribution, and structure of breeding tubercles in the European grayling, Thymallus thymallus (L.) [= Występowanie, rozmieszczenie i budowa wysypki tarłowej u lipienia europejskiego Thymallus thymallus (L.)]. Przegl Zool 26:425-429. (in Polish)

Yamamoto T, Hirohashi N, Fujiwara R, Suzuki T, Maruta H, Omiya H, Kitanishi S (2017) Relationships between body size and secondary sexual characters, and sperm characters in male Dolly Varden char (Salvelinus malma). Ecol Freshw Fish 26:397-402. https://doi.org/10.1111/eff. 12283

Zhang D, Gao F, Jakovlić I, Zou H, Zhang J, Li WX, Wang GT (2020) PhyloSuite: An integrated and scalable desktop platform for streamlined molecular sequence data management and evolutionary phylogenetics studies. Mol Ecol Resour 20:348-355. https://doi.org/10.1093/molbev/ msu300

Zhivotovsky LA, Kim HYu (2015) Morphological Markers of Sex in Pink Salmon Oncorhynchus gorbuscha (Salmonidae). J Ichthyol 55:131-133

Zinovjev EA, Bogdanov VD (2012) Morphobiological Features of the Siberian Grayling (Thymallus arcticus, Thymallidae) of the Polar Urals [= Морфобиологические особенности сибирского хариуса (Thymallus arcticus, Thymallidae) Полярного Урала]. Veterinaria Kubani 4. (in Russian)

Zinovjev EA (2012) Ecology of grayling in the Perm Kama region: a monograph [= Экология хариусов Пермского Прикамья: монография] Perm State National Research University, Perm. 445 p. (in Russian)

Publisher's Note Springer Nature remains neutral with regard to jurisdictional claims in published maps and institutional affiliations. 